
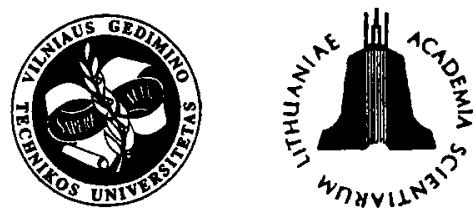

JOURNAL OF CIVIL ENGINEERING AND MANAGEMENT

http:/www.vtu.lt/english/edition

2002, Vol VIII, No 1, 4-33

\title{
ALEKSANDRAS ČYRAS AND OPTIMIZATION IN STRUCTURAL MECHANICS
}

\author{
ANALYTICAL REVIEW \\ Juozas Atkočiūnas ${ }^{1}$, Algirdas Čižas ${ }^{2}$ \\ ${ }^{1}$ Dept of Structural Mechanics, Vilnius Gediminas Technical University, \\ Sauletekio al.11, LT-2040 Vilnius, Lithuania.E-mail: Juozas.Atkociunas@st.vtu.lt \\ ${ }^{2}$ Dept of Strength of Materials, Vilnius Gediminas Technical University, \\ Sauletekio al.11, LT-2040 Vilnius, Lithuania.E-mail: algirdas@skvc.lt
}

Received 3 Jan 2002; accepted 15 Febr 2002

\begin{abstract}
The study describes how in Lithuania (mostly in Vilnius) during some past decades a new trend of investigations in structural mechanics thanks to Aleksandras Čyras' (1927-2001) research and organisational activities has been developed. The main distinguished features of the trend are: application of mathematical programming, and especially the duality theory, to the optimization of elastic-plastic and other structures, formulation of mathematical models of structural mechanics problems, elaborating algorithms and programmes for their solution. The advantages of the research results are shown, a large information concerning the publication of the results and the evolution of investigations initiated by A. Čyras are presented.
\end{abstract}

Keywords: structural mechanics in Lithuania, structural optimization, elastic-plastic structures, strain hardening, shakedown, mathematical programming.

\section{Sources of structural mechanics in Lithuania}

The beginnings of mechanics as science are associated with Vilnius University founded in 1579. During the first two centuries of the University's existence mechanics was taught as a part of physics. In 1780 , by the order of Rector M.Poczobutt the Department (Chair) of Applied Mechanics was established. The list of the lectures delivered by its teachers included the mechanics of solids and liquids. However, the science of mechanics could be developed in Lithuania of those days, especially after closing the University by czarist authorities in 1832 , only by individuals. The engineering and research activities of two former students of Vilnius University N. Jastrzębski (1808-1874) and S. Kerbedis (1810-1899) should be mentioned. In 1837, N. Jastrzębski compiled "The course of practical mechanics" (in Russian). It was the first study guide of practical mechanics in the higher schools of Eastern Europe.

Though science, and especially mechanics, is international by its nature, the development of structural mechanics in Lithuania was effected negatively by the loss of Vilnius University (because of a political confusion in Europe in the first part of the $20^{\text {th }}$ century the capital Vilnius with its region was deprived of Lithuania). Only the nation capable to give the young generation an academic education can regard itself with self-esteem. In the independent Lithuania (though without Vilnius University) the science of structural mechanics was revived at Lithuanian University founded in Kaunas on 16 of February 1922 (from 7 of June 1930, Vytautas Magnus University). By the decision of Lithuanian Seimas (Parliament) on 12 April 1922, the Division of Civil Engineering (at the Technical Faculty) with the Department (Chair) of Structural Mechanics was established. The first head of the Department was appointed Associate Professor Kazimieras Vasiliauskas (1879-1957) [1-5]. Having become Professor in 1930, K.Vasiliauskas ran the Department (which changed its name several times) up to 1 September 1957 [6].

\section{Dates of Lithuanian \\ Structural Mechanics departments:}

12 April 1922: establishment of the Dept of Structural Mechanics at Lithuanian University in Kaunas;

12 April 1922 - 7 June 1930: this Dept is part of Lithuanian University Technical Faculty Civil Engineering Division; 7 June 1930 - 15 August 1940: it is part of Vytautas Magnus University (VMU) Technical Faculty;

1 September 1945 - 1 September 1947: Dept of Structural Statics of VMU, I September 1947 - 15 December 1950: Dept of Structural Mechanics at Civil Engineering Faculty of VMU; 
15 December 1950 - 1 July 1962: Dept of Structural Mechanics at Kaunas Polytechnic Institute (KPI) Hydrotechnical Faculty;

16 March 1962: alongside the Dept of Structural Mechanics, in its base the Dept of Strength of Materials was established (from 1993 on, the Dept of Deformable Solids of Kaunas University of Technology);

Up to 1972 at the KPI Vilnius Division: the Dept of Mechanics where a group of specialists in structural mechanics was being formed;

13 June 1976: at the Vilnius Civil Engineering Institute (Vilniaus inžinerinis statybos institutas, VISI), after transferring a part of the KPI specialists, the activities of the Dept of Structural Mechanics were enlarged here; consequently, the Dept of Structural Mechanics at KPI was closed.

1 August 1976: alongside the Dept of Structural Mechanics, in its base the Dept of Strength of Materials was established. Both Depts continue their activities after reorganising (in 1990) the VISI into the Vilnius Technical University (VTU).

For a long time, even up to 1950 , the only research works in Lithuanian on structural mechanics were 12 articles by Prof K. Vasiliauskas published in journals "Technika" (Kaunas) and "Technische Mechanik" (Stockholm) [7]. K. Vasiliauskas published the monograph "The method of circle in statics" (1929), study guide "Elementary course of strength of materials" (1935). Later, in 1953, K. Vasiliauskas' manual "Principles of structural statics" appeared; it has influenced a more rapid development of structural mechanics in Lithuania [7]. Thus Corresponding member of Lithuanian Academy of Sciences K. Vasiliauskas (1946) can be regarded as the initiator of strength of materials and classical stuctural mechnics in the Independent Lithuania $[8,9]$.

In such a context the future Academician of Lithuanian Academy of Sciences Aleksandras Čyras (19272001) started his activities as researcher. After graduating with honours (in 1950) from the Vytautas Magnus University (the Faculty of Civil Engineering) and acquiring the Diploma of civil engineer, he began $\mathrm{PhD}$ studies and in 1954 defended his Doctoral thesis "Investigation into building frame structures by the optical method" (scientific supervisor Prof K. Vasiliauskas). Up to 1960 the list of his scientific publications is not large some twenty articles and writings (Appendix 1) [10]. He was a co-author of the manual (1959) on strength of materials [11]. Real efforts leading the future researcher to the developing of a new research trend were started about 1960. It is considered that namely at that time Vilnius, the KPI Vilnius Division, administered by Assoc Prof Doctor A. Cyras became the research centre of Lithuanian structural mechanics. A large group of researchers investigating structural mechanics problems worked there.

\section{Structural mechanics in Vilnius}

Practically all the research, pedagogical and organisational activities of Academician Aleksandras Čyras as the founder of the Vilnius Civil Engineering Institute (VISI) and its first Rector is closely connected with Vilnius [12-14], at first with the Vilnius Branch of Kaunas Polytechnic Institute (VB KPI). In 1958, he became the first regular teacher of the academic staff there. In 1960, when the VB KPI became the KPI Evening Faculty, A.Čyras was appointed its Dean. Since 1961, when instead of the KPI Evening Faculty, the Vilnius Division of KPI was established with its full-time and part-time studies, he performed the duties of a Vice-Rector. Besides, A.Čyras was an initiator of establishing the first (in Vilnius) higher technical school - the Vilnius Civil Engineering Institute (VISI, now Vilnius Gediminas Technical University, VGTU); in addition, he was its Rector of many years' standing (1969-1990). As the administrator, A.Čyras did much for strengthening the material base of the VISI, when building new premises for teaching and research, when recruting a creative and productive research and teaching staff. In 1972, on the basis of the existing Dept of Mechanics he established the Dept of Structural Mechanics and was its Head up to September 1, 1987. After closing the Dept of Structural Mechanics at KPI in 1974, the Dept of Structural Mechanics of VISI became the continuer of history and deeds of the Dept of Structural Mechanics established in 1922 at Kaunas University $[3,5,8,9]$.

A. Cyras linked far-sightedly the future develoment of structural mechanics with modern applied mathematics and computing technology. He was the first in Eastern Europe and former USSR to start using methods of mathematical programming for optimizing structures. In 1965, he maintained the thesis of Doctor Habil degree based on some new approaches: "Methods of mathematical programming for designing elastic-plastic one-dimensional systems" [15] (it should be mentioned that the $4^{\text {th }}$ part of the thesis was sagaciously devoted to the developing and prospective trend of mechanics, namely stochastic methods of designing and optimizing the elasticplastic systems). A. Čyras became Professor in 1968. At the Vilnius Division of KPI, by his efforts a group of young researchers for solving mechanical problems was rallied: J. Barauskas, R. Baronas (1941-1999), A. Borkauskas (A.Borkowski), A. Čižas, H. Gylys, V. Zakarevičius, etc. From several points of view, under different conditions they analysed the optimization of elastic-plastic bar (beam, frame, truss) systems. In the works of structural mechanics researchers moved from KPI, as P. Baublys, A. Krutinis, A. Senuta, (a little later L.Lindišas), the calculation of structures on elastic foundation and the stability of bar systems were investigated by methods of mathematical programming.

Having accumulated some experience in formulating and solving particular problems, theoretical questions of optimizing not only bar systems but also plates and shells were analysed. A considerable contribution has been made into the optimization theory of elastic-plastic structures, the practical application of mathematical programming methods, the development of algorithms by a 


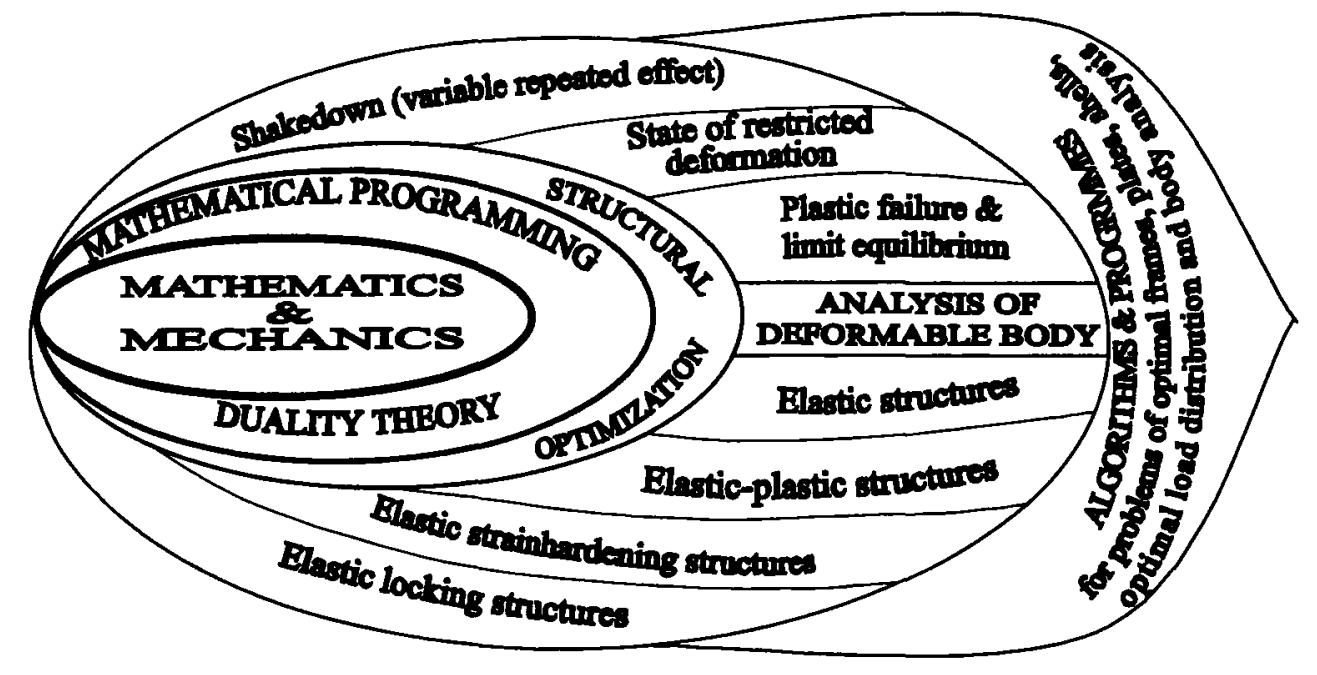

Fig 1. Deformable body optimization research initiated by A. Cyras

large group of A. Čyras' disciples, namely J. Nagevičius, R. Karkauskas, J. Atkočiūnas, S. Kalanta, S. Mažuolis (1934-1989), V. Dulman, K. Vislavičius, R. Kačianauskas, V. Skaržauskas, L. Rimkus, L. Čiupaila, A. Sokas, A. Daniūnas, N. Žukas, R. Fliotovienè (R. Kazakevičiūte-Makowska), R. Baušys, A. Norkus, S. Valentinavičius, as well as Prof A. Čižas and his disciples: V. Kamaitis, S. Stupak, M. Šukšta, A. Komka, J. Medzvieckas (Appendixes 2,3). Problems of synthesis of optimal pin-jointed structures and other mechanical aspects were investigated by Prof D. Maciulevičius (1928-1998) and his disciples A. Čiučelis, A. Kuzmickas, R. Nogis, P. Baradokas, R. Belevičius, R. Kutas, etc. The listed groups are united by the research goal (optimization) and methodology (mathematical programming) ([16-19], Fig 1). An interesting result of A. Čyras' investigations is developing in 1971 the theory of optimization of elastic locking body [10]; A.Borkauskas and his disciple P. Cyras investigated this item as well.

Up to 1996 A. Čyras compiled about 180 articles ([10, 17-19], Appendixes 1, 4). The first monography by A. Čyras "Methods of linear programming for analysis of elastic-plastic structures" [20] can be regarded as an example of a successful substantiation of a comparatively young research branch, namely the application of mathematical programming to optimization of structures. Prof A. Čyras has written 8 monographs (Table 1). Through them the achievements of Lithuanian researchers

Table 1. Monographs of A. Čyras and his disciples

\begin{tabular}{|c|l|}
\hline No & \multicolumn{1}{|c|}{ Monography } \\
\hline 1. & $\begin{array}{l}\text { Čyras A. Methods of linear programming for calculations of elastic-plastic structures. Leningrad: Strojizdat, 1969. 199 } \\
\text { p. (in Russian). }\end{array}$ \\
\hline 2. & Čyras A. Theory of optimization in limit analysis of a solid deformable body. Vilnius: Mintis, 1971. 124 p. (in Russian) \\
\hline 3. & $\begin{array}{l}\text { Čyras A., Borkowski A., Karkauskas R. Theory and methods of elastic-plastic structures. Leningrad: Strojizdat, } 1974 . \\
280 \text { p. (in Russian). }\end{array}$ \\
\hline 4. & $\begin{array}{l}\text { Čyras A. Optimization theory in the design of elastic-plastic structures. Structural optimization: CISM courses and } \\
\text { lectures, 1975, No 237. Berlin: Springer-Verlag, p. 81-150. }\end{array}$ \\
\hline 5. & $\begin{array}{l}\text { Čyras A. Optimization problems in theory of plasticity. Duality and complementarity in mechanics of solids. Wroclaw, } \\
1979, \text { p. 95-172. }\end{array}$ \\
\hline 6. & $\begin{array}{l}\text { Čyras A. Mathematical models for the analysis and optimization of elastic-plastic structures. Vilnius: Mokslas, 1982. } \\
112 \text { p. (in Russian). }\end{array}$ \\
\hline 7. & $\begin{array}{l}\text { Čyras A. Mathematical models for the analysis and optimization of elastoplastic structures. Chichester: Ellis Horwood } \\
\text { Limited, 1983. 121 p. }\end{array}$ \\
\hline 8. & $\begin{array}{l}\text { Borkowski A. Analysis of skeletal structural systems in the elastic and elastic-plastic ranges. Warsaw-Poznan, } 1985 . \\
200 \text { p. (in Polish); PWN-Elsevier, 1988. 200 p. (in English). }\end{array}$ \\
\hline 9. & $\begin{array}{l}\text { Atkočiūnas J. Design of elastic-plastic systems under repeated loading. Vilnius: Science and encyclopaedic publishing } \\
\text { house, 1994. 148 p. (in Russian). }\end{array}$ \\
\hline 10. & Čyras A., Fliotoviene R. Theory of locking. Vilnius: Technika, 1995. 76 p. (in Russian). \\
\hline 11. & Kačianauskas R. Computer methods in multi-level modelling of beams and shells. Vilnius: Technika, 1995. 396 p. \\
\hline
\end{tabular}


concerning the optimization theory of structures have become known and acknowledged in Great Britain, Italy, the USA, Poland, former USSR countries, Germany, etc. A. Cyras delivered lectures on the theory and methods of the deformable body and structural optimization at the International Centre of Mechanics in Udine (Italy), some foreign universities. In 1980 he was elected Corresponding member of Lithuanian Academy of Sciences, in 1985 Member of LA of Sciences. In 1985 he became Honorary Doctor of Weimar Higher School of Construction and Architecture. He was also elected foreign member of: Polish Academy of Sciences (1994), the Polish society of theoretical and applied mechanics (1982), Russian national committee of theoretical and applied mechanics (1985). He was member of editorial boards of some international periodicals of mechanics: "Mechanical Research Communications" (USA), "Prikladnaja mekhanika" ("Applied Mechanics", Ukraine), "Stroitelnaja mekhanika i raschet sooruzhenij" ("Structural Mechanics and Computation of Structures", Russia).

A research school is acknowledged if it publishes systematically the results of its investigations in widely known journals. A. Čyras and A. Čižas were initiators of publishing "Lithuanian Proceedings in Mechanics" (LPM), some issues of which also used to appear for some time under additional headings (Table 2). This journal was being spread in many countries. Because of poor publishing conditions, the LPM issues used to appear later than it was written on the title page [21], but the scientific ideas and research results, though proclaimed

Table 2. Titles of "Lithuanian Proceedings in Mechanics" volumes in 1978-1989

Vol 19 Mathematical Analogues and Algorithms for Problems of Applied Mechanics, 1978

Vol 20 Optimization in Structural Mechanics, 1979

Vol 21 Structural Dynamics and Strength, 1979

Vol 22 Mathematical Analogues and Algorithms for Design of Deformable Structures, 1980

Vol 23 Engineer Problems in Applied Mechanics, 1981

Vol 24 Formulating and Solving Problems of Structural Mechanics, 1981

Vol 25 Dynamics and Strength of Machines and Structures, 1982

Vol 26 Problems of Theoretical and Applied Mechanics, 1983

Vol 27 Applied Mechanics and Optimization, 1984

Vol 28 Investigations in Structural Strength and Dynamics, 1986

Vol 29 Solution Methods for Problems of Structural Mechanics, 1987

Vol 30 Theoretical and Applied Problems of Mechanics, 1988

Vol 31 Mechanics of Deformable Structures, 1989

a little later, were met attentively not only in Lithuania. Many Lithuanian scientists were among the permanent contributors of the journal, and they represented, of course, different branches of research (Table 3). Published for a long time in Russian (with additional Lithuanian and English summaries), the issue No 33 published in English (in 1994) represented a new trend in Lithuanian scientists' cooperation. After the research periodicals integration by Science Council of Lithuania, the LPM stopped to be published and the results of mechanical investigations could be found in journals "Statyba" ("Civil Engineering") and "Mechanika" (Prof A. Čyras was among the members of editorial boards of these periodicals, too). The "Lithuanian Proceedings in Mechanics" contributed much to the propagation of the ideas of Vilnius' school of optimizational structural mechanics and their international recognition.

The application of mathematical programming to structural optimization appeared to be successful [22]. In 1969, a large scientific conference was convened (with many representatives from research centres of the former USSR) in Vilnius for discussing the application of mathematical programming for computing optimal structures. Under the guidance of Prof A. Čyras, further international conferences on problems of optimization and reliability in structural mechanics took place in Vilnius (in 1967, 1971, 1974, 1977, 1979, 1983 and 1988). The Dept of Structural Mechanics of Vilnius Gediminas Technical University (VGTU), following the VISI traditions, supervises now the section "Structural optimization and new design methods" at the international conference "New building materials, structures and techniques". This

Table 3. Subject areas of the LPM papers

\section{Subject area}

Mathematical programming for the structural analysis . . . . . . . .

\section{Structural optimization:}

$\begin{array}{lccc}\text { General items . . . . . . . } & 3 & 1 & 2 \\ \text { Elastic behaviour . . . . . } & 24 & 7 & 6 \\ \text { Plastic behaviour . . . . . } & 19 & 23 & 20 \\ \text { Creeping . . . . . . . . } & - & 3 & 3\end{array}$

Mechanical analysis of structural members:

\begin{tabular}{|c|c|c|}
\hline Statics . & 9 & 12 \\
\hline Dynamics . . . . . . . . & 2 & 11 \\
\hline Mechanics of structures in a liquid & 6 & 8 \\
\hline Mechanics of fracture . . . . . . & 2 & 5 \\
\hline $\begin{array}{l}\text { Experimental investigations, } \\
\text { mechanical properties of materials . }\end{array}$ & 19 & - \\
\hline Anaksis and design of mechanisms. . & 1 & 12 \\
\hline Other ... & 5 & 9 \\
\hline
\end{tabular}


conference in Vilnius is being organised (since 1991) by the Faculty of Civil Engineering.

Under the supervision of Academician A. Čyras 27 Doctoral theses have been maintained. His eight collaborators and disciples became Habilitation Doctors: D. Maciulevičius, A. Čižas, A. Borkauskas, R. Belevičius, R. Kačianauskas, J. Atkočiūnas, M. Leonavičius, R. Baušys (Table 4). In Vilnius, some general trends of research on mechanics of solid deformable body have emerged under the guidance of Academician A. Kudzys, Prof D. Maciulevičius (1928-1999), Prof A. Čižas. Some of them, especially their ties with the theory of optimization of solid deformable body developed by A. Čyras will be discussed in detail further.

For a long time (1969-1991) there existed at the VISI Dept of Structural Mechanics the Laboratory of Structural Mechanics [23, 24] which performed valuable commissioned research (Appendix 5). The research items carried out by the members of Dept of Structural Mechanics were included in the complex research of 19801985 programme of the former USSR under the title "Suggestions concerning the selection of design diagrams and methods for mass construction buildings and structures" [25]. These suggestions of Vilnius investigators

Table 4. Habilitation theses in structural mechanics

\begin{tabular}{|c|c|c|c|}
\hline No & Author & Habilitation thesis & Date \\
\hline 1. & $\overline{\text { A. C̆yras }}$ & $\begin{array}{l}\text { Methods of mathematical } \\
\text { programming to analysis } \\
\text { of elastic-plastic one- } \\
\text { dimensional systems }\end{array}$ & 1965 \\
\hline 2. & D. Maciulevičius & $\begin{array}{l}\text { Methods of mathematical } \\
\text { programming in the } \\
\text { problems of truss systems }\end{array}$ & 1969 \\
\hline 3. & A. Čižas & $\begin{array}{l}\text { Theory and methods for } \\
\text { design of optimal elastic- } \\
\text {-plastic strain-hardening } \\
\text { structures }\end{array}$ & 1974 \\
\hline 4. & A. Borkowski & $\begin{array}{l}\text { Mathematical } \\
\text { programming in problems } \\
\text { of non-linear statics }\end{array}$ & 1978 \\
\hline 5. & R. Belevičius & $\begin{array}{l}\text { Computer algebra in } \\
\text { finite element method }\end{array}$ & 1994 \\
\hline 6. & R. Kačianauskas & $\begin{array}{l}\text { Computer methods in } \\
\text { multilevel modelling of } \\
\text { beams and shells }\end{array}$ & 1996 \\
\hline 7. & J. Atkočiünas & $\begin{array}{l}\text { Design of elastic-plastic } \\
\text { systems under repeated } \\
\text { loading }\end{array}$ & 1996 \\
\hline 8. & M. Leonavičius & $\begin{array}{l}\text { Cyclic fracture strength } \\
\text { and shakedown of } \\
\text { threaded joints and } \\
\text { connected elements }\end{array}$ & 2000 \\
\hline 9. & R. Baušys & $\begin{array}{l}\text { Quality assessed finite } \\
\text { element analysis for } \\
\text { structural dynamic and } \\
\text { acoustic problems }\end{array}$ & 2000 \\
\hline
\end{tabular}

were added to the Recommendations for designing building structures compiled for practical purposes by the USSR Central Institute for Building Construction Research in Moscow.

The Laboratory of Structural Mechanics where investigations into materials cyclic strength took place was later transferred to the Dept of Strength of Materials guided by Prof A. Čižas $[26,27]$. On the base of its structure, the Research laboratory for strength mechanics has been established (supervised by Prof M. Leonavičius).

The Head of the Dept of Structural Mechanics (of VISI) Prof A. Čyras was an active propagator of new scientific ideas among students, the future engineers. Two articles published by him $(1968,1969)$ and dealing with the duality in the problems of structural mechanics, elasticity and plasticity $[28,29]$ have disclosed a new viewpoint on problems of structural mechanics and elasticity theory, as well as on the methods of teaching them. Based on extremal energy principles, the problems of strength design of elastic and elastic-plastic systems are formulated here in a dual form. The theory of convex programming duality is applied for it. Different conditions of structural design, different loading cases are analysed. Prof A. Čyras has distinguished himself by a clear pedagogical talent. Unfortunately, the administrative and research activities connected with large work loads, frequent trips did not allow him to deliver lectures continually. It should be noted his constant worry: what things are the most urgent today, what subjects should be the future engineers taught? Thanks to Rector A. Čyras' initiatives and persistence, the VISI was orientated 30 years ago to a very large application of computers in teaching process (here an important role of Dept of Applied Mathematics and Mechanics administrated by Prof D. Maciulevičius should be mentioned). A. Čyras directed personally the efforts to restructure the curricula of structural mechanics and the teaching methodology. Today we could say that he fostered the seedlings of an informational society.

Prof A. Čyras used to write and publish study guides on modern structural mechanics for Bachelor, Master and Doctoral students (Table 5). The acknowledgement of efforts of the Dept of Structural Mechanics (of VISI) for introducing the theory of structural optimization and methods into academic studies can be the syllabus of structural mechanics of the former USSR [30]. In this syllabus, the list of the main reference items includes the books of the VISI scientists: A. Čyras, A. Borkauskas, R. Karkauskas [31]. A group of researchers of the Dept of Structural Mechanics of VTU - A. Čyras (scientific supervisor), R. Karkauskas, A. Krutinis, J. Atkočiūnas, S. Kalanta, J. Nagevičius - were awarded in 1993 Lithuanian State Prize for a complex of computerised study guides of structural mechanics.

For the application of mathematical methods in structural mechanics Academician A. Čyras was awarded the prize of B. Galorkin (1968), Lithuanian State Prizes 
Table 5. Textbooks in Structural Mechanics and Strength of Materials written by academic staff of VISI (VGTU)

\begin{tabular}{|l|l|}
\hline No & \multicolumn{1}{|c|}{ Manual } \\
\hline 1. & $\begin{array}{l}\text { Čižas A., Viršilas V., Žekevičius J. Problems of } \\
\text { strength of materials with solutions and comments. } \\
\text { Vilnius: Mokslas, 1985, 278 p.; 2-nd edition - Vilnius: } \\
\text { TEV, 2000, 295 p. (in Lithuanian) }\end{array}$ \\
\hline 2. & $\begin{array}{l}\text { Čyras A. Structural mechanics. Theory and algorithms. } \\
\text { Moscow: Strojizdat, 1989. 225 p. (in Russian) }\end{array}$ \\
\hline 3. & $\begin{array}{l}\text { Čyras A. Structural Mechanics. Vilnius: Mokslas, } \\
\text { 1990. 448 p. ( in Lithuanian) }\end{array}$ \\
\hline 4. & $\begin{array}{l}\text { Karkauskas R., Krutinis A., Atkočiūnas J., Kalanta S., } \\
\text { Nagevičius J. Structural mechanics. Programmes and } \\
\text { solution of problems by PC. Moscow: Strojizdat, 1990. } \\
\text { 360 p. (in Russian) }\end{array}$ \\
\hline 5. & $\begin{array}{l}\text { Čižas A. Strength of materials. Mechanics of structural } \\
\text { members. Vilnius: Technika, 1993. 408 p. (in } \\
\text { Lithuanian) }\end{array}$ \\
\hline 6. & $\begin{array}{l}\text { Karkauskas R., Krutinis A., Atkočiūnas J., Kalanta S., } \\
\text { Nagevičius J. Solution of structural mechanics } \\
\text { problems by computers. Vilnius: Science and } \\
\text { Encyclopaedic Publishing House, 1995. 264 p. (in } \\
\text { Lithuanian). }\end{array}$ \\
\hline 7. & $\begin{array}{l}\text { Atkočiūnas J., Nagevičius J. Fundamentals of theory } \\
\text { of elasticity. Vilnius: Technika, 2000. 262 p. (in } \\
\text { Lithuanian) }\end{array}$ \\
\hline 8. & $\begin{array}{l}\text { Rimkus L., Skaržauskas V. Structural mechanics of } \\
\text { plain bar systems. Vilnius: Technika, 2000. 156 p.; } \\
\text { 2-nd edition - Vilnius: Technika, 2001. 165 p. (in } \\
\text { Lithuanian) }\end{array}$ \\
\hline 9. & $\begin{array}{l}\text { Krutinis A. Design theory and methods of structures } \\
\text { on elastic basement. Vilnius: Technika, 2001. 168 p. } \\
\text { (in Lithuanian) }\end{array}$ \\
\hline
\end{tabular}

$(1976,1993)$. For merits in the field of Lithuanian science and education he was decorated with the Order (the $3^{\text {rd }}$ degree) of Grand Duke Gediminas (1996).

\section{Scientific heritage of Aleksandras Čyras}

\subsection{General features}

The scientific research heritage of A. Cyras is large and of a rather wide range. But it is not difficult to discern a clear trend of analysis of structural mechanics problems. First of all, the researcher tried to base his best scientific endeavours on fundamental (energy) principles of mechanics. Having applied the latest mathematical methods (mathematical programming), he has found fine mathematical expressions for these principles, dual mathematical models of structural mechanics problems. Though his main goal was optimization of structures, the scientist has disclosed that the theory and methods of mathematical programming also make clearer the ordinary analysis of structures (not only the optimizational one) [28, 29]. Broad scientific vistas of A. Cyras' thinking are also seen from another point of view. Though he was mainly engaged in research of elastic perfectly plastic material structures, he did not forget the elastic systems either [32, 33] and found spare time to take a glance at a novel model - plastic strain-hardening one. Systematising the entire domain of structural mechanics problems, he classified these problems from different points of view.

The main goal of structural design is to define its strength, stiffness and stability. The parameters of each problem describe three principal elements of a structure: loading, body geometry, and material (Fig 2). A problem of structural mechanics can be solved when all the element parameters are known. A. Čyras recommended calling such problems the analysis problems. In his opinion, the reason is that when solving such a problem, only the state of the body's stress and strain is determined, ie the body is analysed from the mechanical point of view: by a comparison with the service (maintenance) requirements we determine whether a structure is sufficiently strong, stiff and stable.

If some of the above parameters are not defined in advance, the problem becomes undetermined and we need some supplementary conditions for resolving it. Thus we are to analyse not the body itself but, after defining certain limits of the deformable body (after formulating strength, stiffness or stability requirements), we should pursue our selected object (to look for a suitable loading, suitable geometry or a proper material). In this way an extremum problem results and, having solved it, not only stresses and strains are found, but also certain parameters of loading, body geometry or material. The apparatus for solving the extremum problem is based on the mathematical programming theory and methods.

Variations may be performed with different quantities. For instance, when the point of load application and load direction are selected, different solutions of the problem (ie different stresses and strains of the body) are obtained by changing merely the load magnitude. For a deformable body (with its geometry and material selected) many distributions of load may be found which correspond to definite design conditions. Having selected any criterion of load suitability, it is possible to find from all these distributions the best one, the optimal distribution. For instance, the criterion of load suitability may be the total load magnitude, possibly a maximum load is being strived after. Such problems are called load optimization problems (at the beginning A.Čyras called them checking problems). The load parameters sought may be interconnected by additional conditions; for instance, all loading forces may be expressed by a single load parameter (such a parameter is called single-parametrical).

For the engineering design experience, the body physical parameters optimization problem is important (Prof A. Cyras used to call it simply the design problem). In this case, the loading is known, and very many combinations of physical parameters of structural elements may be found and all of them can satisfy the design conditions. The optimality criterion of such combinations may be, for instance, the structure price (the cheapest structure is looked for). In addition, A. Čyras analysed the pro- 


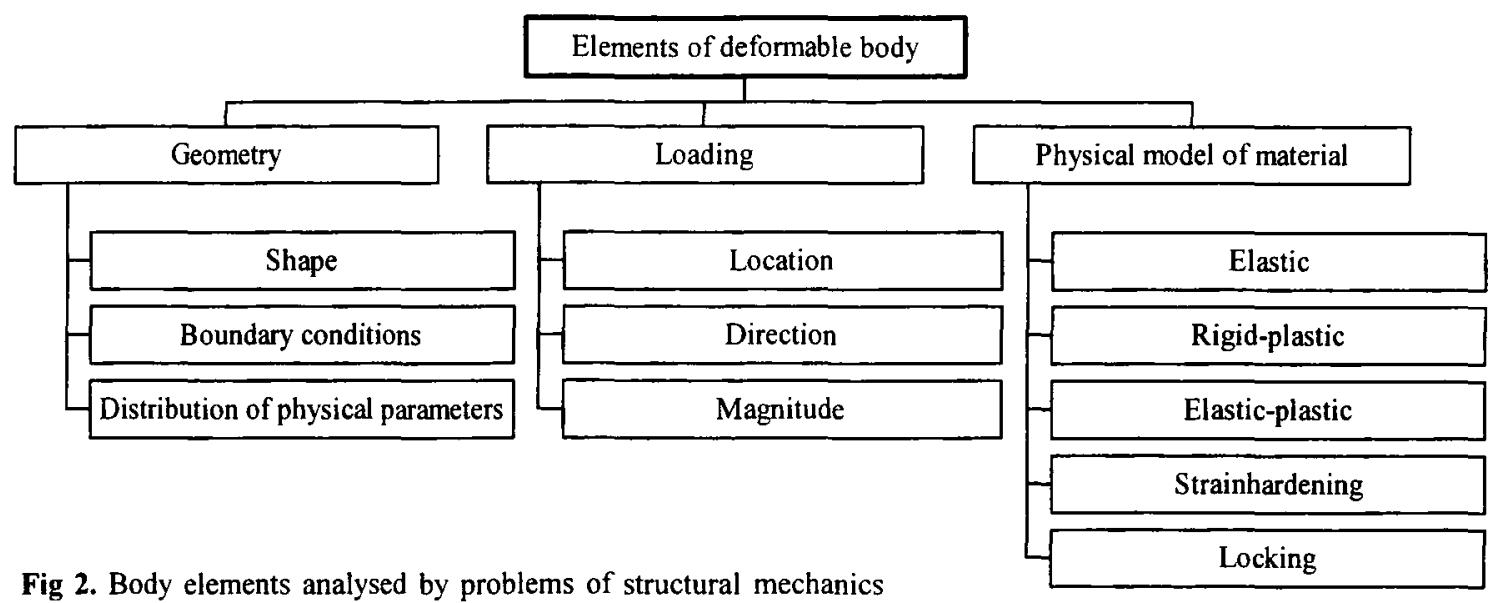

blems of optimal geometry of structure (structural synthesis) $[34,35]$.

Prof A. Čyras kept to such a structural mechanical problems classification in all his researching efforts $[20$, 34]. It is very clearly expressed in his report at all-USSR scientific conference devoted to optimizational structural mechanics questions in Vilnius in 1979 [35]. In this booklet, different optimization problems are considered as based on the main factors determining the mechanics of deformed solids. These factors include, firstly, the external actions defined by their value, the direction and point of application and, secondly, the solid itself defined by the configuration, as well as the distribution of physical parameters and the conditions of support. All these characteristics may be varied according to a certain optimality criterion of either the external actions or the solid. Hence different types of optimization problems are obtained.

In course of time A. Čyras and his disciples have analysed more complicated structures, with more diverse physical peculiarities. First of all the theory of rigid plastic body optimization for the case of monotonically increasing load should be mentioned; it was developed by A. Čyras, A. Borkauskas, R. Karkauskas [33, 35-38]. The theory was devoted to the case of an ideal elasticperfectly plastic body affected by cyclic loading [3942]. By the efforts of A. Čyras himself, by A. Borkauskas, A. Čižas, later on by J. Atkočiūnas, this theory and design methods based on it were improved not once [4346]. At the same time A. Cyras together with R. Fliotovienè $[47,48]$ analysed the problems of elastic locking body, and with V. Dulman [49] the optimization problems of the body under creep.

The analysis of stress and strain of the elastic-plastic body being in state prior to plastic collapse is extremely important [38, 42]; it was initiated by A. Čyras, R. Baronas, A. Čižas as far back as 1966 [50-52]. The ways of calculating the stresses and strains of the state prior to collapse having been explained, the research passed on the elastic-plastic structures optimization problems under displacement constrains [53-58].
Already in the thesis of 1965 and his first monography [20] A. Cyras described the design of elastic-plastic structures, when the structural parameters and outer effects are random values and functions. He has presented design models, methods and algorithms for two cases: the determined structure and stochastic loading, the determined loading and stochastic material. These investigations by A. Cyras were highly appreciated by the specific branch of mathematics, theory of probability specialists, Academicians V. Bolotinas, V. Statulevičius. Later, A. Čyras and A. Norkus continued investigations into the field of stochastic structural optimization. Here they have formulated problems for a simple loading taking into account the stochastic nature of plastic structure parameters and outer effects, using also the kinematic formulation of the problem. This article [59] devoted to the methods of elastic-plastic framed structures stochastic optimization was one of the last works in A. Čyras research activities.

As it has been already mentioned, A. Čyras started his main investigations into the optimization of elasticplastic structures about 1963 and continued them up to 1993, up to a considerable worsening of his health. Thus it is worth looking at the beginnings of A. Cyras' research activities in the context of foreign scientists' investigations dealing with the optimization of structures [60].

Though the theory of optimal structural design is being developed for a considerable span of time, the first studies concerning the theory appeared in the 1950s [61, 62]. The first book of a generalising character may be considered [63] (1965). Its author H. L. Cox paid much attention to the engineering aspects of structural optimization, but in the book there is nothing about computer applications in this field. In general, the book by $\mathrm{H}$. L. Cox has now only some historical value.

A. Čyras was among the first researchers in the former USSR who started applying mathematical programming methods and computers for optimization of deformable structures. In this aspect the book of Polish scientist Z. Leśniak [64] (1970) is of great importance; in it the use of computers is mostly based on the random se- 
arch method. This author was the first who has applied for structural optimization the non-linear programming method and used it for design of a simple structure, most often a beam. P. Hupfer in his book [65] (1970) presented a review (without his own investigations) of general methods of more complicated structures than those analysed in Z. Leśniak's monograph.

J.-L. Armand's book [66] (1971) largely and deeply analyses one optimal design method, namely optimal control of distributed parameters systems. The book contains many examples of bar and plate volume optimization when limiting eigenfrequencies of vibration. The author adheres to the system (characteristic of structural optimization theorists-mathematicians) when applying the mathematical programming theory to this field: often at first the required conditions for partial derivatives in terms of non-linear equations are defined for the examined problem optimal solution and then their discretization is performed. In our opinion, Prof A. Čyras has selected a more prospective way for engineering practice, namely to discretize the optimality criterion equations in the initial stage of forming the mathematical model of the problem. It is naturally achieved by applying in structural mechanics the numerical method of finite element or other method. Physical meaning of objective function is entirely clear in such mathematical models of optimization. In the period under discussion (1974), W. Prager's book [67] was published; theoretical principles of establishing the optimality criterions of elastic structures are dealt with there. But in the book there is nothing about the mathematical programming application to the optimization of structures (though some articles by V. Prager on the subject discussed are known). More data concerning the mathematical programming application to calculating plastic structures in the period discussed may be found in the book [68] and review publication [69].

In this context the first steps were taken by A. Čyras, the pioneer of Lithuanian optimizational structural mechanics. In the structural optimization theory development the main roles were played by computers and the theory of non-linear mathematical programming. These two factors allowed to solve technical problems by which a solution adequate to the optimality criteria could be found.

\subsection{Application of mathematical programming dua- lity theory}

From the mathematical point of view the optimization problems are more complicated than those of analysis. Their solution without numerical methods and computer technologies is almost impossible. Along the development of electronic computational technologies since 1963 in Vilnius new calculating methods for structural mechanics have been established. Inefficient classical calculation methods for dealing with complex structures and external actions are substituted by numerical methods al- lowing to formulate and solve the structural problems that could not be solved earlier (physical and partly geometrical non-linearities, optimization problems, etc.). Taking into account plastic properties of structural material reflects in a more exact way the structural behaviour at different loading stages and allows to elaborate its more rational project. Application of extremum energy principles, the linear mathematical programming theory is characteristic of investigations directed by A. Čras. Such an attitude allowed to analyse the problem of frame optimization by the dual - static and kinematic - problem formulation. On the base of duality theory, the peculiarities of linear mathematical models have been disclosed and proofs of many theorems presented (such proofs being in want in research literature). A. Čyras highly appreciated the possibilities of the mathematical programming duality theory. In his opinion, a practical interpretation of mathemathical programming problems is possible only by using the duality theory.

In A. Ćyras' first monograph [20], the frame verifying and its design problem was successfully analysed basing it namely on the duality theory of linear mathematical programming. The author has underlined that the design of discrete structures in the range of elastic behaviour is a completely investigated domain of structural mechanics. To his mind, a correct canonical formulation of structural mechanics analysis problems has allowed to take advantage of the methods of solving the linear algebraic equation system. The matrix formulation and electronic technology only supported it. In the meanwhile, as it has been remarked in A. Cyras' monograph, the development of methods for tie design of elastic-plastic structures had fallen behind the modern applied mathematics and computer technology, even as concerns their possibilities of those days. Also, the problems of structural optimization had been dealt poorly with. The monograph by A. Cyras' was the first to change essentially the situation in this domain. In addition, it has not lost today its scientific value because it initiated the analysis of the state of strain before the plastic failure of frame.

Later A. Cyras wrote about the mathematical programming duality theory in mechanics [70]: "It is known from the mathematical programming theory that for every extremum problem a dual problem can be made. As a result, a widely known statement of mechanics is corroborated that every extremum principle of the solids mechanics formulated by force variables corresponds to the dual principle expressed in terms of strain state variables. In mechanics these principles are usually formulated separately. But the mathematical programming duality theory allows getting them in a pure formal way. With that end in view Lagrange function is constructed and it consists of the objective functions of the primary problem and conditions of the primary problem multiplied by certain variables. Further, for satisfying the stationarity conditions of Lagrange function, its variations with respect to the variables of the initial problem are put 
equal to zero. These are namely the conditions of a dual problem. After formal mathematical rearrangements it is not difficult to disclose the physical meaning of the new extremum problems by words as well". The application of the mathematical programming duality theory attended A. Cyras' investigations through all his scientific achievements and became a solid basis for his most conclusions.

\subsection{Deformable body optimization theory (limit equi- librium)}

In 1969, A. Čyras and A. Borkauskas published an article [71] in which the fundamentals of the deformable body optimization theory based on the application of nonlinear mathematical programming were presented. In the article, the verifying and design problem at one-time loading is analysed. The authors of the article adhered to the following statements:

1. The problems of structural design for strength are to be formulated by dual extremum energy principles. The problem is to be formulated first of all by static variables (it is static formulation). The kinematic formulation of the problem is obtained according to mathematical programming duality theory. In this case the physical meaning of the dependencies, equations and variables is disclosed easily.

2. The structural strength design problem formulation based on energy principles allows to analyse from common positions the single-parametric and optimizational problems (it is very important when formulating a unified theory of structural design).

3. A visual operator (matrix) form for recording problems is used. It is easily connected with numerical methods of solving problems.

The article [71] begins with static formulation of tie load optimization problem. The goal of such problem solution is determining optimal load distribution and that of stress and strain field at plastic collapse. The deformable body geometry and material are described fully, and the load optimality criterion is as follows:

$$
\int_{S_{f}} \mathbf{T}^{T} \mathbf{q} d S \rightarrow \max .
$$

Here the unknown $\mathbf{q}$ is a load the direction and the addition spot of which are prescribed. Vector $\mathbf{T}$ components show what kind of influence the definite load vector $\mathbf{q}$ component exerts on the whole loading optimality. By choosing various vectors $\mathbf{T}$, it is possible to formulate different optimal load distribution problems. For instance, if $\mathbf{T} \equiv 1$ at every point of the body surface $S_{f}$, the criterion (3.1) enables to determine the maximum total load at the body surface [72]. If vector $\mathbf{T}$ components are equal to the point displacement rate $(\mathbf{T} \equiv \dot{\mathbf{u}})$, then (3.1) expresses the power $\dot{W}$ of external forces $\mathbf{q}$.

The stress state of rigid-plastic body at the plastic failure is determined by the extremum energy principle.
A. Cyras suggested to call this principle the statical theorem of limit load and formulated it in this way:

of all the statically admissible stress vectors at plastic failure, the actual one is maximizing the power of the load.

This energy principle is realised by such a mathematical model of extremum problem:

$$
\begin{aligned}
& \int_{S_{f}} \dot{\mathbf{u}}^{T} \mathbf{q} d S \rightarrow \max , \\
& \left\{\begin{array}{l}
\nabla \mathbf{\sigma}=\mathbf{0}, \\
f(\mathbf{\sigma}) \leq C \quad \in V ; \\
\mathbf{N o}-\mathbf{q}=\mathbf{0}, \\
\mathbf{q} \geq \mathbf{0} \quad \in S_{f} ; \\
\mathbf{N o}-\mathbf{r}=\mathbf{0} \in S_{u} .
\end{array}\right.
\end{aligned}
$$

Here $f$ is the yield function. The unknowns of the problem (3.2)-(3.3) are vectors of the load $\mathbf{q}$, stresses $\boldsymbol{\sigma}$, reactions $\mathbf{r}$. It is a problem of convex non-linear mathematical programming. Displacement rates $\dot{\mathbf{u}}$ are not included in the problem (3.2)-(3.3) conditions. Therefore the maximum of the external load $\mathbf{q}$ power may be determined with any values of $\dot{\mathbf{u}}$, thus also with $\dot{\mathbf{u}}=\mathbf{T}$ ( $T$ is vector of the load optimality criterion (3.1) weight coefficients). Thus because of the coincidence of the energy principle and load optimization goals, from the problem (3.2)-(3.3) the mathematical model of the load optimization problem for rigid-plastic body appears:

$$
\int_{S_{f}} \mathbf{T}^{T} \mathbf{q} d S \rightarrow \max
$$

under the same (3.3) conditions.

The extremum energy principle realised by this problem ensures that the actual stress vector obtained by an optimal solution is real, though in the problem formulation there are no equations of geometrical compatibility. The optimal solution of the static formulation of problem (3.2)-(3.3) is marked by $\mathbf{q}^{*}, \boldsymbol{\sigma}^{*}, \mathbf{r}^{*}$.

The optimization problem kinematic formulation has been obtained by applying the non-linear mathematical programming duality theory:

$$
\begin{gathered}
\left\{\int_{V} \boldsymbol{\sigma}^{T} \lambda \frac{\partial f(\boldsymbol{\sigma})}{\partial \boldsymbol{\sigma}} d V+\int_{V} \lambda[C-f(\boldsymbol{\sigma})] d V\right\} \rightarrow \min , \\
\qquad\left\{\begin{array}{c}
\nabla^{T} \dot{\mathbf{u}}-\lambda \frac{\partial f(\boldsymbol{\sigma})}{\partial \boldsymbol{\sigma}}=\mathbf{0}, \\
\lambda \geq 0 \quad \in V ; \\
\dot{\mathbf{u}} \geq \mathbf{T} \quad \in S_{f} \\
\dot{\mathbf{u}}=\mathbf{0} \quad \in S_{u} .
\end{array}\right.
\end{gathered}
$$

When the load is expressed by a single parameter $q_{0}$ and a known load distribution $\eta$ : 


$$
\mathbf{q}=q_{0} \mathbf{\eta},
$$

the static formulation problem model is obtained from the general mathematical model (3.4)-(3.3) after rearranging power in the objective function (3.2) as follows:

$$
\dot{W}=\int_{S_{f}} \dot{\mathbf{u}}^{T} \mathbf{q} d S=q_{0} \int_{S_{f}} \dot{\mathbf{u}}^{T} \mathbf{n} d S .
$$

By equating the integral value to unity -

$$
\int_{S_{f}} \dot{\mathbf{u}}^{T} \boldsymbol{\eta} d S \equiv 1
$$

a load single-parametric mathematical model of the problem is obtained:

$$
\begin{gathered}
q_{0} \rightarrow \max , \\
\left\{\begin{array}{l}
\nabla \boldsymbol{\sigma}=\mathbf{0}, \\
f(\boldsymbol{\sigma}) \leq C, \in V ; \\
\mathbf{N} \boldsymbol{\sigma}=q_{0} \boldsymbol{\eta} \in S_{f}, \\
\mathbf{N} \boldsymbol{\sigma}-\mathbf{r}=\mathbf{0} \in S_{u} .
\end{array}\right.
\end{gathered}
$$

The optimal solution of this problem is $q_{0}, \mathbf{\sigma}, \mathbf{r}$.

A. Čyras frequently applied a graphical presentation for mathematical programming problems: the problem (3.10)-(3.11) domain is shown in Fig 3. Here load parameter $F_{0}$ is sought when the equilibrium equations are $\boldsymbol{\eta} F_{0}-\boldsymbol{A ~} \mathbf{0}=\mathbf{0}$.

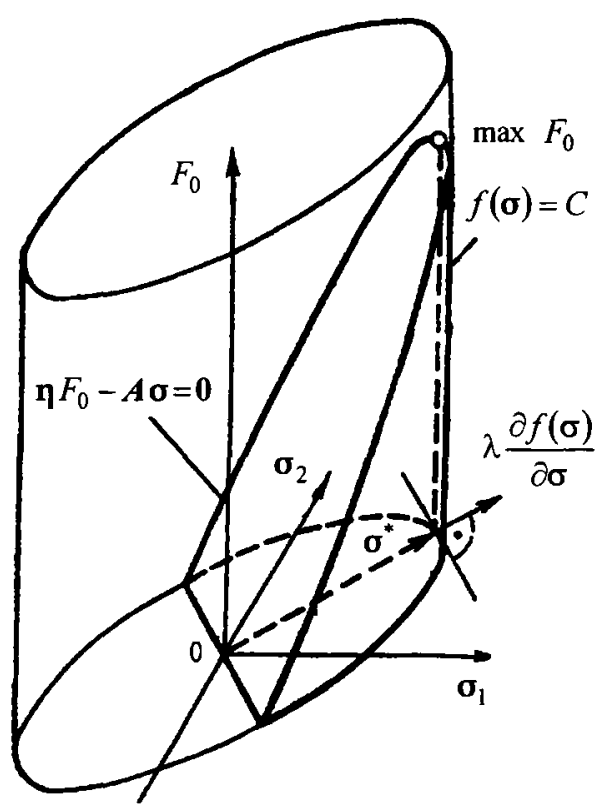

Fig 3. Graphical view of the problem domain when defining the allowable loading
The design problem aim is to define the body stress and strain field at plastic failure and the optimal distribution of body plasticity constants $C$. In this case the external loading $\mathbf{q}$ is known, and the objective function is:

$$
\int_{V} \Lambda C d V \rightarrow \min .
$$

Here $\Lambda$ is a scalar function of optimality criterion coefficients. The meaning of the criterion (3.12) is explained by using the discrete structure representation. Let the plasticity constant $C$ of any cross-section of a discrete structure be the function $C \equiv C\left(\sigma_{y}, h\right)$ of the material yield stress $\sigma_{y}$ and the sectional characteristic dimension (eg, height $h$ ). Hence, after defining $h=$ const and properly selecting $\Lambda$ under the condition that the price is proportional to integral $\int \sigma_{y} d V$, (3.12) may mean the aim of structural material price minimization. On the other hand, having defined $\sigma_{y}=$ const and properly selected $\Lambda$, it is possible to obtain the height (volume) minimization problem.

The constant $C$ optimal distribution associated with plastic failure is determined according to extremum energy principle (A. Čyras called this principle as static plastic failure theorem):

of all statically admissible stress vectors at plastic failure, the actual one is minimizing the energy dissipation rate.

According to this principle, the mathematical model of rigid-plastic body design problem is as follows:

$$
\begin{aligned}
& \int_{V}^{\Lambda C d V \rightarrow \min ,} \\
& \left\{\begin{array}{lr}
\nabla \boldsymbol{\sigma}=\mathbf{0}, \\
C-f(\boldsymbol{\sigma}) \geq 0, \\
C \geq \mathbf{0} \quad \in V^{\prime} \\
\mathbf{N} \boldsymbol{\sigma}=\mathbf{q} \quad \in S_{f} \\
\mathbf{N o}-\mathbf{r}=\mathbf{0} & \in S_{u} .
\end{array}\right.
\end{aligned}
$$

The problem solved, the distribution of stress vector $\boldsymbol{\sigma}^{*}$ and optimal $C^{*}$ is found in volume $V$. Both in case (3.4)-(3.3) and (3.13)-(3.14) are problems of convex non-linear programming.

\subsection{Cyclic plastic failure and shakedown}

A variable repeated loading represents the system of forces when each of these forces or their groups may change independently. Under such loading a structure may lose its serviceability because of its progressive plastic failure or because of alternating strains. Melan's and Koiter's theorems are known as capable to describe conditions of an elastic-plastic body's shakedown or inadaptation to loading conditions [73]. In this section the 
task is restricted to the load determination problems' static and kinematic formulations which are based on extremum energy principles assigned to ideal elastic perfectly plastic body (analogous to those used in $3.3 \mathrm{sec}-$ tion and devoted to rigid-plastic body). The static formulation of the load determination problem is composed by such an energy principle:

of all statically admissible residual stress vectors at cyclic plastic failure, the actual one is maximising the power of external loads in a cycle.

This principle is realised by the following mathematical model of problem:

$$
\begin{gathered}
\left\{\int_{S_{f}} \mathbf{T}^{+T} \mathbf{q}^{+} d S+\int_{S_{f}} \mathbf{T}^{-T} \mathbf{q}^{-} d S\right\} \rightarrow \max \\
\left\{\begin{array}{l}
\nabla \boldsymbol{\rho}=\mathbf{0}, \\
f\left(\mathbf{\sigma}^{+}+\boldsymbol{\rho}\right) \leq C, \\
f\left(\mathbf{\sigma}^{-}+\boldsymbol{\rho}\right) \leq C \in V \\
\mathbf{N} \boldsymbol{\rho}=\mathbf{0}, \\
\mathbf{q}^{+} \geq \mathbf{0}, \quad \mathbf{q}^{-} \geq \mathbf{0} \in S_{f} \\
\mathbf{N} \boldsymbol{\rho}-\mathbf{r}=\mathbf{0} \quad \in S_{u}
\end{array}\right.
\end{gathered}
$$

Here $\boldsymbol{\sigma}^{+}, \boldsymbol{\sigma}^{-}$are the extremum stresses obtained for the imaginary stage of unlimited elasticity, $\mathbf{q}^{+}$and $\mathbf{q}^{-}$ are functions of the load $\mathbf{q}$ bounds.

The kinematic formulation of a load determination problem is constructed according to the following energy principle:

of all kinematically admissible residual displacement rates vectors at cyclic plastic failure, the actual one is minimizing the energy dissipation in a cycle. blem:

This statement is realised by such extremum pro-

$$
\begin{aligned}
& \left\{\int_{V} \boldsymbol{\sigma}^{+T} \lambda^{+} \frac{\partial f\left(\boldsymbol{\sigma}^{+}+\boldsymbol{\rho}\right)}{\partial \boldsymbol{\rho}} d V+\int_{V} \boldsymbol{\sigma}^{-T} \lambda^{-} \frac{\partial f\left(\boldsymbol{\sigma}^{-}+\boldsymbol{\rho}\right)}{\partial \boldsymbol{\rho}} d V+\right. \\
& \left.+\int_{V} \lambda^{+}\left[C-f\left(\boldsymbol{\sigma}^{+}+\boldsymbol{\rho}\right)\right] d V+\int_{V} \lambda^{-}\left[C-f\left(\boldsymbol{\sigma}^{-}+\boldsymbol{\rho}\right)\right] d V\right\} \rightarrow \text { min }
\end{aligned}
$$

$$
\left\{\begin{array}{c}
-\lambda^{+} \frac{\partial f\left(\boldsymbol{\sigma}^{+}+\boldsymbol{\rho}\right)}{\partial \boldsymbol{\rho}}-\lambda^{-} \frac{\partial f\left(\boldsymbol{\sigma}^{-}+\boldsymbol{\rho}\right)}{\partial \boldsymbol{\rho}}+\nabla^{T} \dot{\mathbf{u}}=\mathbf{0} \\
\lambda^{+} \geq 0, \quad \lambda^{-} \geq 0
\end{array} \in V\right.
$$

$$
\left\{\begin{array}{c}
\lambda^{+} \frac{\partial f\left(\mathbf{\sigma}^{+}+\boldsymbol{\rho}\right)}{\partial \mathbf{q}^{+}}+\lambda^{-} \frac{\partial f\left(\mathbf{\sigma}^{-}+\boldsymbol{\rho}\right)}{\partial \mathbf{q}^{+}} \geq \mathbf{T}^{+} \\
\lambda^{+} \frac{\partial f\left(\boldsymbol{\sigma}^{+}+\boldsymbol{\rho}\right)}{\partial \mathbf{q}^{-}}+\lambda^{-} \frac{\partial f\left(\mathbf{\sigma}^{-}+\boldsymbol{\rho}\right)}{\partial \mathbf{q}^{-}} \geq \mathbf{T}^{-} \in S_{f} \\
\dot{\mathbf{u}}=\mathbf{0} \in S_{u}
\end{array}\right.
$$

It may happen that the optimal problem (3.17)(3.18) solution will include both non-zero multipliers corresponding to tie same body point: $\lambda^{+}$and $\lambda^{-}$. It would mean that at this point the alternating plastic strain takes place. If only one of the multipliers $\left(\lambda^{+}\right.$or $\left.\lambda^{-}\right)$equals zero, the progressive failure takes place at the point. It should be remarked that the failure type is a result of the problem (3.17)-(3.18) solution but not a result of any preliminary consideration [39].

The mathematical models (3.15)-(3.16) and (3.17)(3.18) make a dual pair of mathematical programming problems. By applying them it is possible to determine the bounds of load variation without analysing the loading history and only selecting various optimality criteria. According to the second duality theorem, the optimal solutions of problems (3.15)-(3.16) and (3.17)-(3.18) (the variables of optimal solution are marked by asterisks) satisfy the following conditions:

$$
\begin{aligned}
& \int_{V} \lambda^{+*}\left[C^{*}-f\left(\boldsymbol{\sigma}^{+*}+\boldsymbol{\rho}^{*}\right)\right] d V=0, \\
& \int_{V} \lambda^{-*}\left[C^{*}-f\left(\boldsymbol{\sigma}^{-*}+\boldsymbol{\rho}^{*}\right)\right] d V=0 .
\end{aligned}
$$

These are the complementary slackness conditions known in mathematical programming theory. The equality

$$
\begin{gathered}
\int_{S_{\mathrm{f}}} \mathbf{T}^{+T} \mathbf{q}^{+*} d S+\int_{S_{\mathrm{f}}} \mathbf{T}^{-T} \mathbf{q}^{-*} d S=\int_{V} \boldsymbol{\sigma}^{+* T} \lambda^{+*} \frac{\partial f\left(\boldsymbol{\sigma}^{+*}+\boldsymbol{\rho}^{*}\right)}{\partial \boldsymbol{\rho}} d V+ \\
+\int_{V} \boldsymbol{\sigma}^{-* T} \lambda^{-*} \frac{\partial f\left(\mathbf{\sigma}^{-*}+\boldsymbol{\rho}^{*}\right)}{\partial \boldsymbol{\rho}} d V
\end{gathered}
$$

written according to the first duality theorem means that the load power in an actual loading cycle is equal to the energy dissipation rate in the cycle. For any cycle $t$ from (3.20) the Koiter's shakedown condition [73] is obtained:

$\int_{0}^{t} \int_{S_{f}} \dot{\mathbf{u}}^{T}(\mathbf{x}, t) \mathbf{q}(\mathbf{x}, t) d S d t \leq \int_{0}^{t} \int_{V} \mathbf{\sigma}^{T}(\mathbf{x}, t) \dot{\varepsilon}(\mathbf{x}, t) d V d t$.

A. Čyras has underlined in [39] that the inequality (3.21) is merely a result of analysis of solutions of dual problems (3.15)-(3.16) and (3.17)-(3.18) made on the basis of extremum energy principles.

A. Čyras also analysed some special variable loading cases, for instance, the influence of movable loading [74]. The research by A. Čras, his disciples and followers dealing with the state of cyclically loaded elastic perfectly plastic body and structures of lineariy strainhardening material joined the group of researchers from the former USSR and foreign countries discussing the shakedown theory $[68,69,75-79]$.

\subsection{Analysis of deformable body}

After solving the limit equilibrium problem the stresses and rates of displacements are determined under a 
special body state, namely at its plastic failure. In an engineering practice one must often know the state of a structure which has been subjected to a plastic strain prior to plastic failure. According to the classification suggested by A. Čyras, such a problem is called the body's (structure's) analysis problem. It is often solved stage by stage. The stage method is widely spread in engineering; however, it requires much work and is insufficiently conditioned when the loads approach the limit loads.

A. Čyras, under some influence of A. Procenko's early works [80], has recommended the method allowing to determine the state of stress and strain without analysing the history of body loading, but only knowing the final loading values. For the static formulation of the analysis problem, the extremum principle concerning the minimum of complementary energy is used. The static formulation allows to determine real residual stresses. The dual kinematic principle is a means for describing the body's strain state at any loading stage.

Static formulation of the analysis problem. The elastic perfectly plastic body with its volume $V$ and the surface $S$ is analysed. In volume $V$, scalar field of the plasticity constant $C$ is given. On the surface part $S_{f}$, a load defined by the vector field $\mathbf{q}$ is given, whereas on the surface part $S_{u}$ (on a supporting surface) the displacements $\mathbf{u}=\mathbf{0}$ are presented. The vector field of true stresses is noted, as earlier, by $\sigma$. These are stresses which develop in a body at any stage of its loading before the complete plastic failure. Stresses $\sigma_{e}$ are determined as if the system discussed were of an indefinitely ideal elasticity:

$$
\boldsymbol{\sigma}_{e}=\int_{S_{f}} \mathbf{\alpha} \mathbf{q} d S
$$

Here $\mathbf{a}$ is algebraic operator of elastic problem (for a discrete structure it would be an influential matrix). After adding self-balancing residual stresses $\rho$

$$
\boldsymbol{\sigma}=\boldsymbol{\sigma}_{e}+\boldsymbol{\rho} .
$$

The variables of strain state are decomposed analogically:

$$
\boldsymbol{\varepsilon}=\varepsilon_{e}+\varepsilon_{r}, \quad \mathbf{u}=\mathbf{u}_{e}+\mathbf{u}_{r} .
$$

Here the pseudo-elastic deformations (corresponding to the apparent stage of infinite elasticity) and displacements are noted as $\varepsilon_{e}$ and $\mathbf{u}_{e}$, residual strains and displacements $\varepsilon_{r}$ and $u_{r}$ respectively. Based on the extremum principle:

of all statically admissible stress vectors of body in state prior to the plastic failure, the actual one is minimizing the complementary energy of deformation

the mathematical model of analysis problem static formulation is composed:

$$
\frac{1}{2} \int_{V} \rho^{T}[D] \rho d V \rightarrow \min ,
$$

$$
\begin{aligned}
& \nabla \boldsymbol{\rho}=\mathbf{0}, \quad f\left(\boldsymbol{\sigma}_{e}+\boldsymbol{\rho}\right) \leq C \quad \in V ; \\
& \mathbf{N} \boldsymbol{\rho}=\mathbf{0} \quad \in S_{f}, \\
& \mathbf{N} \boldsymbol{\rho}-\mathbf{r}=\mathbf{0} \quad \in S_{u} .
\end{aligned}
$$

Here $[D]$ is the algebraic matrix of Hooke's law; $f$ is yield function. After solving the problem of convex nonlinear mathematical programming (3.25)-(3.26), an actual vector of residual stresses $\rho^{*}$ and reactions $\mathbf{r}^{*}$ are obtained.

Kinematic formulation of the analysis problem is obtained by using the mathematical programming duality theory:

$$
\begin{gathered}
\left\{-\frac{1}{2} \int_{V} \boldsymbol{\rho}^{T}[D] \boldsymbol{\rho} d V-\int_{V}\left[\boldsymbol{\rho}^{T} \lambda \frac{\partial f\left(\boldsymbol{\sigma}_{e}+\boldsymbol{\rho}\right)}{\partial \boldsymbol{\rho}}\right]^{T} d V-\right. \\
\left.-\int_{V} \lambda\left[C-f\left(\boldsymbol{\sigma}_{e}+\boldsymbol{\rho}\right)\right] d V\right\} \rightarrow \max , \\
\nabla^{T} \mathbf{u}_{r}=[D] \boldsymbol{\rho}+\lambda \frac{\partial f\left(\boldsymbol{\sigma}_{e}+\boldsymbol{\rho}\right)}{\partial \boldsymbol{\rho}}, \quad \lambda \geq 0 \in V, \\
\mathbf{u}_{r}=\mathbf{0} \in S_{u} .
\end{gathered}
$$

The unknowns of the problem (3.27)-3.28) are $\rho$, $\mathbf{u}_{r}$ and $\lambda$. The condition (3.28) denotes the geometric compatibility equations $\nabla^{T} \mathbf{u}_{r}=\varepsilon_{r}$ associating the residual displacements $\mathbf{u}_{r}$ and residual strains $\boldsymbol{\varepsilon}_{r}$ :

$$
\varepsilon_{r}=\varepsilon_{r e}+\varepsilon_{p}, \quad \varepsilon_{r}=[D] \rho, \quad \varepsilon_{p}=\lambda \frac{\partial f\left(\boldsymbol{\sigma}_{e}+\boldsymbol{\rho}\right)}{\partial \boldsymbol{\sigma}_{r}},
$$

and defines kinematically admissible field of residual displacements $\mathbf{u}_{r}$. If the sign of the objective function (3.27) is changed by the opposite one, the following problem is obtained

$$
\begin{gathered}
\left\{\frac{1}{2} \int_{V} \boldsymbol{\rho}^{T}[D] \boldsymbol{\rho} d V+\int_{V}\left[\boldsymbol{\rho}^{T} \lambda \frac{\partial f\left(\mathbf{\sigma}_{e}+\boldsymbol{\rho}\right)}{\partial \boldsymbol{\rho}}\right]^{T} d V+\right. \\
\left.+\int_{V} \lambda\left[C-f\left(\boldsymbol{\sigma}_{e}+\boldsymbol{\rho}\right)\right] d V\right\} \rightarrow \min , \\
\nabla^{T} \mathbf{u}_{r}=[D] \boldsymbol{\rho}+\lambda \frac{\partial f\left(\mathbf{\sigma}_{e}+\boldsymbol{\rho}\right)}{\partial \boldsymbol{\rho}}, \quad \lambda \geq 0 \in V, \\
\mathbf{u}_{r}=\mathbf{0} \in S_{u} .
\end{gathered}
$$

This problem conforms to the extremum energy principle:

of all admissible fields of residual displacements in an elastic-plastic body the actual one is minimizing the total strain energy of unloaded body.

The discussed mathematical models of analysis problems are valid for the load $q$ varying in the interval $\mathbf{q}_{T} \leq \mathbf{q} \leq \mathbf{q}_{0}$. Here $\mathbf{q}_{T}$ is the upper value of the exter- 
nal loads which does not result in plastic strains. If $\mathbf{q} \leq \mathbf{q}_{T}$, the system is working in the elastic stage and the values of the objective functions (3.25) and (3.30) are equal to zero.

In 1980, A.Čyras, applying the extreme energy principle about the minimum of elastic potential of residual stresses, compiled dual mathematical models of problems for determining tie elastic-plastic body stresses and strains under tie shakedown state.

\subsection{Optimization of elastic-plastic systems with re- stricting displacements}

When possible displacements are constrained by stiffness requirements, an elastic-plastic structure may not reach the limit stage connected with plastic failure. The optimization of elastic-plastic framed structures with restricted displacements was subjected to an analysis by A. Čyras together with A. Čižas already in 1966 [50, 52]. The mathematical model of the load optimization problem for the elastic perfectly plastic body before the plastic failure was designed by J.Atkočiūnas in 1983 [56]. A. Čyras published in 1984 the article on mathematical models of elastic perfectly plastic systems optimization problems with restriction of displacements and linear yield conditions [57]. This article of A. Čyras may be regarded as distinguished by its clearness and consistency: the states of stress and strain satisfy in this case the extremum energy principles concerning complementary and total strain energy minimum.

When the structural material is not perfectly plastic, the plastic failure is impossible; then the limit state of the structure is defined only through limiting the strains and displacements. A. Čižas was one of the pioneers in the field of investigations of optimizing structures from linearly strain-hardening material in the former USSR at that time $[44,53]$. A little later A. Čyras devoted an article [58] for aspects of linearly strain-hardening material structures optimization for cases of monotonic loading, cyclic loading and movable loading. In this investigation the author has remarked that it is necessary to include the displacement restrictions into mathematical models of optimization problems for elastic-plastic strainhardening structures. Thus it is necessary to determine true strains and displacements in any - both monotonically increasing and cyclic - loading case. In the author's opinion, here variables are not the summary stresses, displacements or strains but their residual components.

The state of stress of linearly strain-hardening elastic-plastic discrete system is characterised by vectors of the true $\mathbf{S}$, the residual $\mathbf{S}_{r}$ and the elastic $\mathbf{S}_{e}$ stresses: $\mathbf{S}=\mathbf{S}_{e}+\mathbf{S}_{r}$ (Fig 4). The residual stresses satisfy the equilibrium equations $[A] \mathbf{S}_{r}=\mathbf{0}$. Displacements $\mathbf{u}=\mathbf{u}_{e}+\mathbf{u}_{r}$ and strains $\mathbf{q}=\mathbf{q}_{e}+\mathbf{q}_{r}$. The residual strains $\mathbf{q}_{r}$ consist of two parts - residual elastic $\mathbf{q}_{r e}$ and residual plastic $\mathbf{q}_{r p}: \mathbf{q}_{r}=\mathbf{q}_{r e}+\mathbf{q}_{r p}$. The equations of geometric compatibility are as follows: $[A]^{T} \mathbf{u}_{r}=\mathbf{q}_{r}$. Obtained by elasti-

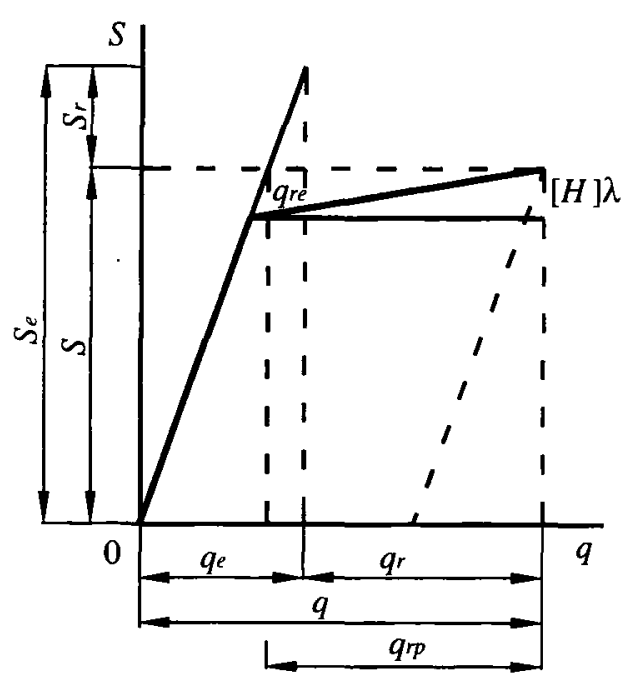

Fig 4. Relation of stresses and strains for linearly strainhardening structures

city calculation, stresses $\mathbf{S}_{e}=[\alpha] \mathbf{F}$ and displacements $\mathbf{u}_{e}=[\beta] \mathbf{F}$, here $\mathbf{F}$ is vector of external loading. The plactic properties of the structure are defined by limit stress vector $\mathbf{S}_{0}$ as well as by matrices of yield matrix $[\Phi]$ and symmetric matrix of strain-hardening $[H]$. The yield condition for a kinematic strain-hardening case is

$$
\mathbf{S}_{0}-[\Phi] \mathbf{S}_{r}+[\Phi] \mathbf{S}_{e}+[H] \lambda \geq \mathbf{0}
$$

Here $\lambda$ is vector of multipliers.

The static formulation of analysis problem is made according to the following energy principle:

of all statically admissible vectors of residual stresses, the actual one is minimizing the sum of elastic potentials of self-balanced stresses and strain-hardening.

Thus the following mathematical model of the problem in static formulation is obtained:

$$
\begin{array}{r}
\left(\frac{1}{2} \mathbf{S}_{r}^{T}[D] \mathbf{S}_{r}+\frac{1}{2} \lambda^{T}[H] \lambda\right) \rightarrow \min , \\
\mathbf{S}_{0}-[\Phi] \mathbf{S}_{r}+[\Phi] \mathbf{S}_{e}+[H] \lambda \geq \mathbf{0}, \quad[A] \mathbf{S}_{r}=\mathbf{0} .
\end{array}
$$

The mathematical model in kinematic formulation of analysis problem is as follows:

$$
\left(-\frac{1}{2} \mathbf{S}_{r}^{T}[D] \mathbf{S}_{r}-\frac{1}{2} \lambda^{T}[H] \lambda+\lambda^{T}\left([\Phi] \mathbf{S}_{e}-\mathbf{S}_{0}\right)\right) \rightarrow \max
$$

$$
[D] \mathbf{S}_{r}+[\Phi]^{T} \lambda-[A]^{T} \mathbf{u}_{r}=\mathbf{0}, \quad \lambda \geq \mathbf{0} .
$$

By using the analysis problem, influence relationships of residual displacements and stresses $\mathbf{u}_{r}=[\Lambda] \lambda$, $[\Phi] \mathbf{S}_{r}=[\Gamma] \lambda$, displacement restrictions

$$
\mathbf{u}^{-} \leq[L] \mathbf{u} \leq \mathbf{u}^{+},
$$


the mathematical model of monotonic load optimization problem is made:

$$
\begin{gathered}
\varphi\left(\mathbf{S}_{0}\right) \rightarrow \min , \\
\boldsymbol{\Psi}^{\prime}=[G] \mathbf{S}_{0}-[\Gamma] \lambda+[H] \lambda-[\gamma]^{T}[\beta] \mathbf{F} \geq \mathbf{0}, \\
\mathbf{u}^{-} \leq[L][\beta]([\gamma] \lambda+\mathbf{F}) \leq \mathbf{u}^{+}, \quad \lambda^{T} \boldsymbol{\Psi}^{\prime}=0, \\
\lambda \geq \mathbf{0}, \quad \mathbf{S}_{0} \geq \mathbf{0} .
\end{gathered}
$$

Here $\varphi$ is the scalar function of optimality criterion. The conditions of the mathematical model unite the (3.33)(3.34) and (3.35)-(3.36) restrictions allowing to obtain the state of stresses and strains. The mathematical model may also be rearranged for perfectly elastic-plastic system.

The variable repeated loading $\mathbf{F}(t)$ is characterised by the upper bounds $\mathbf{F}^{+}$and the lower ones $\mathbf{F}^{-}$. The extreme stresses at every hodograph apex $i \in I$ are calculated according to formulas:

$$
\begin{gathered}
\mathbf{S}_{e i}^{+}=\left[\alpha_{i}^{+}\right] \mathbf{F}^{+}+\left[\alpha_{i}^{-}\right] \mathbf{F}^{-}, \\
\mathbf{S}_{e i}^{-}=\left[\alpha_{i}^{-}\right] \mathbf{F}^{+}+\left[\alpha_{i}^{+}\right] \mathbf{F}^{-}, \\
{\left[\alpha_{i j}^{+}\right]+\left[\alpha_{i j}^{-}\right]=[\alpha] .}
\end{gathered}
$$

Then the true residual stresses are found after solving the static formulation analysis problem:

$$
\begin{gathered}
\left(\frac{1}{2} \mathbf{S}_{r}^{T}[D] \mathbf{S}_{r}+\frac{1}{2} \sum_{i}\left(\lambda_{i}^{+}\right)^{T}[H] \lambda_{i}^{+}+\right. \\
\left.+\frac{1}{2} \sum_{i}\left(\boldsymbol{\lambda}_{i}^{-}\right)^{T}[H] \lambda_{i}^{-}\right) \rightarrow \min \\
\left\{\begin{array}{c}
\mathbf{S}_{0}-[\Phi] \mathbf{S}_{r}-[\Phi] \mathbf{S}_{e i}^{+}+[H] \lambda_{i}^{+} \geq \mathbf{0} \\
\mathbf{S}_{0}-[\Phi] \mathbf{S}_{r}-[\Phi] \mathbf{S}_{e i}^{-}+[H] \lambda_{i}^{-} \geq \mathbf{0}, \quad i \in I \\
{[A] \mathbf{S}_{r}=\mathbf{0}}
\end{array}\right.
\end{gathered}
$$

With the help of Lagrange function the dual problem is obtained:

$$
\begin{aligned}
& \left(-\frac{1}{2} \mathbf{S}_{r}^{T}[D] \mathbf{S}_{r}-\frac{1}{2} \sum_{i}\left(\lambda_{i}^{+}\right)^{T}[H] \lambda_{i}^{+}-\frac{1}{2} \sum_{i}\left(\lambda_{i}^{-}\right)^{T}[H] \lambda_{i}^{-}+\right. \\
& \left.+\sum_{i}\left(\lambda_{i}^{+}\right)^{T}\left([\Phi] S_{e i}^{+}-S_{0}\right)+\sum_{i}\left(\lambda_{i}^{-}\right)^{T}\left([\Phi] S_{e i}^{-}-S_{0}\right)\right) \rightarrow \max ,
\end{aligned}
$$

$$
\left\{\begin{array}{c}
{[D] \mathbf{S}_{r}+[\Phi]^{T} \sum_{i}\left(\boldsymbol{\lambda}_{i}^{+}+\boldsymbol{\lambda}_{i}^{-}\right)-[A]^{T} \mathbf{u}_{r}=\mathbf{0},} \\
\boldsymbol{\lambda}_{i}^{+} \geq \mathbf{0}, \quad \boldsymbol{\lambda}_{i}^{-} \geq \mathbf{0},
\end{array}, i \in I\right.
$$

In his article [58] A. Cyras has remarked that the strain state of dissipative systems depends on the loading history which is not known in case of a variable repeated loading. Thus the mathematical model (3.42)(3.43) is preferred in cases when the phenomenon of un- loading does not exist. Then the mathematical model of optimization problem for the structure made of strainhardening material is as follows:

$$
\begin{gathered}
\varphi\left(\mathbf{S}_{0}\right) \rightarrow \min , \\
\Psi_{1 i}=[G] \mathbf{S}_{0}-[\Phi] \mathbf{S}_{r}-[\Phi] \mathbf{S}_{e i}^{+}+[H] \lambda_{i}^{+} \geq \mathbf{0}, \\
\Psi_{2 i}=[G] \mathbf{S}_{0}-[\Phi] \mathbf{S}_{r}-[\Phi] \mathbf{S}_{e i}^{-}+[H] \lambda_{i}^{-} \geq \mathbf{0}, \\
{[A] \mathbf{S}_{r}=\mathbf{0},} \\
{[D] \mathbf{S}_{r}+[\Phi]^{T} \sum_{i}\left(\lambda_{i}^{+}+\boldsymbol{\lambda}_{i}^{-}\right)-[A]^{T} \mathbf{u}_{r}=\mathbf{0},} \\
\mathbf{u}^{-} \leq[L]\left(\mathbf{u}_{e i}^{+}+\mathbf{u}_{r}\right) \leq \mathbf{u}^{+}, \quad \mathbf{u}^{-} \leq[L]\left(\mathbf{u}_{e i}^{-}+\mathbf{u}_{r}\right) \leq \mathbf{u}^{+}, \\
\left(\lambda_{i}^{+}\right)^{T} \boldsymbol{\Psi}_{1 i}=\mathbf{0}, \quad\left(\lambda_{i}^{-}\right)^{T} \boldsymbol{\Psi}_{2 i}=0, \quad \lambda_{i}^{+} \geq \mathbf{0}, \quad \lambda_{i}^{-} \geq \mathbf{0}, \\
\mathbf{S}_{0} \geq \mathbf{0}, \quad i \in J .
\end{gathered}
$$

Here $\mathbf{u}_{e i}^{+}$and $\mathbf{u}_{e i}^{-}$are pseudo-elastic extremum displacements. After removing the variables $S_{r}$ and $\mathbf{u}_{r}$ the final mathematical model of optimization problem is obtained:

$$
\begin{gathered}
\varphi\left(\mathbf{S}_{0}\right) \rightarrow \min , \\
\boldsymbol{\Psi}_{1 i}^{\prime}=[G] \mathbf{S}_{0}-[\Gamma] \sum_{i}\left(\lambda_{i}^{+}+\lambda_{i}^{-}\right)+[H] \lambda_{i}^{+}-[\Phi] \mathbf{S}_{e i}^{+} \geq \mathbf{0}, \\
\boldsymbol{\Psi}_{2 i}^{\prime}=[G] \mathbf{S}_{0}-[\Gamma] \sum_{i}\left(\lambda_{i}^{+}+\boldsymbol{\lambda}_{i}^{-}\right)+[H] \lambda_{i}^{-}-[\Phi] \mathbf{S}_{e i}^{-} \geq \mathbf{0}, \\
\mathbf{u}^{-} \leq[L]\left(\mathbf{u}_{e i}^{+}+[\Lambda] \sum_{i}\left(\boldsymbol{\lambda}_{i}^{+}+\boldsymbol{\lambda}_{i}^{-}\right)\right) \leq \mathbf{u}^{+}, \\
\mathbf{u}^{-} \leq[L]\left(\mathbf{u}_{e i}^{-}+[\Lambda] \sum_{i}\left(\boldsymbol{\lambda}_{i}^{+}+\lambda_{i}^{-}\right)\right) \leq \mathbf{u}^{+}, \\
\left(\lambda_{i}^{+}\right)^{T} \Psi_{1 i}^{\prime}=0, \quad\left(\lambda_{i}^{-}\right)^{T} \boldsymbol{\Psi}_{2 i}^{\prime}=0, \\
\lambda_{i}^{+} \geq \mathbf{0}, \quad \lambda_{i}^{-} \geq \mathbf{0}, \quad \mathbf{S}_{0} \geq \mathbf{0}, \quad i \in J .
\end{gathered}
$$

The unknowns of the problem are vectors $\mathbf{S}_{0}, \boldsymbol{\lambda}_{i}^{+}$, $\lambda_{i}^{-}, i \in I$. The optimization problem (3.38)-(3.39) for the case of a monotonic loading is obtained from the mathematical model (3.46)-(3.47), when $\mathbf{F}=\mathbf{F}^{+}=-\mathbf{F}^{-}$.

In the same article [58] A. Čyras has also pointed out a possibility to apply the problem (3.46)-(3.47) to the possible case of unloading. Thus it is necessary to define the bounds of restricted displacements vector components by solving additional problems. Consequently, the problem (3.46)-(3.47) should be solved by an iterative way.

\subsection{From general mathematical models to structural analysis and optimization}

A. Čyras has formed general mathematical models of analysis and optimization problems for deformable bo- 
dies in a functional space of stresses, strains and displacements (sections 3.3-3.5). However, these models were reached in different ways. For instance, the problems of limit equilibrium at first were solved for frame structures by linear programming. But the mathematical models for design problems of a plate, shallow cylindrical shell were formed, on the contrary, by using general mathematical models of problems (common research with A. Borkauskas [81-83], J. Nagevičius [84-85]). Therefore the above-mentioned (in this section) mathematical models of analysis and optimization problems for discrete structures (especially frame structures) may have produced a direct influence on the results presented in previous sections. A. Čyras and his disciples kept to the rule: theoretical results should be published in scientific issues only after performing an examination by a numerical experiment; but at that time the available computational technology was not able to solve problems of a larger amount. Theoretical conclusions were often verified by samples of frame structures.

When analysing frame structures, a discrete structural model is produced in a very natural way: a frame structure is divided into separate elements and in their cross-sections the values of stresses, strains and displacements are defined, each element being treated as a bar of finite dimensions. At first namely for such discrete frame structures visual and comparatively simple mathematical models of optimization and analysis problems were constructed. Although the notions of limit moment and point yield conditions were used, the mathematical models reflected quite accurately the real work of frame structures [20].

When solving the engineering problems of shallow shells and plates optimization, the investigation turns to the finite vectorial space, the structures are discretized and the conditions of problems mostly become non-linear.

Not only the problems of optimization but also those of analysis of stress and strain state of deformed structure were formulated as mathematical programming (at first as linear, later as non-linear convex) problems. At that time well-known algorithms and what's more programmes were rare occurences. Both algorithms and programmes were to be compiled by the authors of mathematical models, especially when it was necessary to have in mind the specificity of those models. Even a standard simplex algorithm for problems of linear programming was being modified [50]. This modification was applied by $A$. Krutinis and A. Čižas for the optimal distribution of the load of elastic-plastic one-dimensional systems with limited deformation (and resting on a deformable base) [86].

For solving problems of non-linear mathematical programming the gradient projection method by Rozen was taken. It was applied by P. Baublys and I. Cypinas (1969, [87]) for analysing the stability of optimal elastic structures. In 1970, this method was used for the first time by R. Karkauskas for solving non-linear problems of plastic shallow spherical shell optimization in case of a monotonic loading [88-90]. For solving non-linear problems of plates, including the case of variable repeated loading, this algorithm was applied in 1971 by J. Atkočiūnas [91]. And in 1972 the non-linear problem of load determination for a shallow cylindrical shell was solved by S.Kalanta at the Computational Centre of Lithuanian Academy of Sciences using his own developed programme [92] (the first non-linear problems were solved at the established recently the Computational Centre of the VISI by computer "Minsk-22"). The calculations were limited largely by poor computational capabilities at that time.

At the beginning the methods of break lines, finite differences and finite elements were applied for discretization of plates and shells. The method of break lines for the optimization of plates was applied by A. Borkauskas $[81,82,31]$, finite differences - by A. Borkauskas [31], J. Atkočiūnas, S. Kalanta, B. Mažuolis [91]. J. Nagevičius has applied the finite difference method in case of linear yield conditions for optimization of shallow cylindrical shells [84]. R. Karkauskas has developed techniques of finite differences for spherical shell optimization (Fig 5) to be applied to the non-linear Mises yield condition $[88,89,31]$, and S. Kalanta with J. Nagevičius - techniques for cylindrical shell [94]. Rudiments of the finite element method [91] and the equilibrium finite elements $[92,95]$ were introduced.

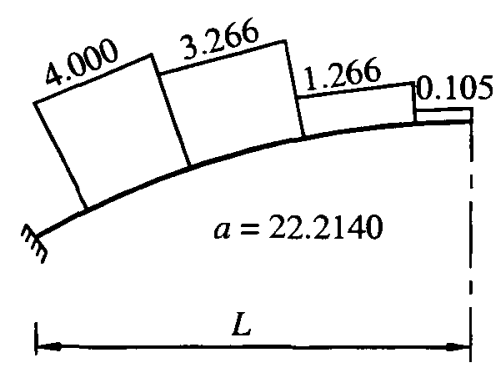

Fig 5. Optimal solution of spherical shell load distribution

Under the guidance of A. Čyras, alongside R. Karkauskas, J. Atkočiūnas, S. Kalanta [96-99], gradually joined P. Cyras [100], K. Vislavičius [101, 102], V. Skaržauskas [103], etc. A considerable contribution was made by S. Kalanta when applying equilibrium finite elements for discretizing elastic-plastic, rigid-plastic structures [92, 95, 98, 99]. For elastic systems, S. Kalanta compiled two alternative algorithms of the equilibrium finite element method [104-106]: those of stiffness (method of displacements) and pliability (method of forces). S. Kalanta has shown by experimental calculations of plates and shells that the equilibrium finite elements surpass by their accuracy the geometrically compatible and mixed finite elements. The scientists of the Dept of Structural Mechanics (supervised by A. Čyras) applied the method of equilibrium finite elements for optimizing elas- 
tic-plastic plates and shells by linking the problems with plastic failure of structures, developed the algorithms and computer programmes for problem solution and analysed numerical problems [107-112] (Appendix 5). A. Čyras, S. Kalanta and R. Kačianauskas found ways for better expressing material yield conditions adapted to finite elements [113-117].

From the problems of plastic failure first of all A. Čižas and his disciples (V. Kamaitis, S. Stupak, M. Šukšta, etc) moved away. They started to deal with structures produced of plastic linearly strain-hardening materials; instead of perfectly plastic hinge conception they got involved in defining plastic deformation spread zones in bars with a real shape cross-sections, and in combining optimal frame structures of a real set of bars [53$55,118-130]$.

About 1979, after formulation by A. Cyras mathematical models of analysis problems for elastic-plastic systems which have not reached a plastic failure [38, 131], his disciples (L. Rimkus, A. Daniūnas, L. Čiupaila, N. Žukas, etc) became engaged in the development of algorithms and programmes for solving these problems. A. Daniūnas has suggested an original method of equilibrium finite elements for computing rectangular plates [135]. The investigations into shakedown analysis problems enlarged under some influence of Polish school of structural mechanics [138-139, 45,140-144]. J. Atkociūnas using the Kuhn-Tucker conditions in order to develop strain compatibility equations for elastic perfectly plastic structures continued the elaboration of methods for computing residual displacements change boundaries [145-147], and began solving optimization problems of frames and plates at shakedown stage [148150].

A. Čyras, R. Baušys, R. Karkauskas began to analyse about 1985 the optimization of perfectly elastic-plastic frame structures with limited displacements. Some improved algorithms have been developed for solving particular problems of optimization [151, 152].

In the course of time a large experience has been accumulated at the Dept of Structural Mechanics of VISI in the field of solving non-linear problems of mathematical programming. It allowed to compile manuals with texts and descriptions of computational programmes suitable for research as well [153-157].

\section{Successors of Aleksandras Čyras' research activi- ties}

There is no doubt that the most intensive development of investigations commenced by A. Čyras took place at the Vilnius Civil Engineering Institute (and it continues to be performed at the Vilnius Gediminas Technical University). Here the main centre of the research of such a direction was and remains the Dept of Structural Mechanics. The Department was headed after A. Čyras by Assoc Prof A. Krutinis (1987-1997), and from the mid- dle of 1997 by Prof J. Atkočiūnas. Namely the majority of the Department' scientists was A. Cyras' disciples and later on the collaborators and co-authors of scientific publications. The extreme energy principles and the theory of mathematical programming introduced by A. Cyras' research in the field of mechanics of solid deformable body have been applied by $\mathrm{A}$. Krutinis for calculating structures on deformable basis [158]. Such a point of view has allowed to analyse the main equations of structures on an elastic ground by the duality theory and to disclose new peculiarities of such mathematical models, to analyse, by using effective modern methods, the state of stress and strain of a system of two deformable bodies (the structure and its ground). Together with A. Čyras, the investigation of the optimization of shallow cylindrical elastic-plastic shells was joined by Assoc Prof J. Nagevicius, of spherical shells (already under non-linear yield conditions) by Assoc Prof R. Karkauskas, the optimization of the repeated variable loading by Prof J. Atkočiūnas [39, 40, 91], the application of finite element method for optimizing shells by Assoc Prof S. Kalanta [92-95], the optimization of arches under movable loading by Assoc Prof V.Skaržauskas [103, 161-163], the effect of temperature on elastic-plastic structures by Assoc Prof L. Rimkus [132, 164, 165], the analysis of locking sistems by Assoc Prof R. Fliotoviene [47, 48, 166], the optimization systems under accidental loading by Assoc Prof A. Norkus [59, 167]. A common work with Prof A. Čyras resulted in an independent creative research for many scientists.

Having taken his first steps in the direction shown by A. Čyras, ie basing his research efforts on the extreme energy principles and mathematical programming duality theory, formulating mathematical models of problems and developing the algorithms for solving these problems, later on J. Atkociūnas analysed intensively elastic-plastic systems affected by repeated variable loading, their shakedown conditions and optimization [145-150, 168-170] and a considerable part of this research has been generalised by a monograph [46]. His field of research interests is the optimal shakedown design of inelastic structures [171-182].

R. Karkauskas has formulated the main dependences of a generalized shape surface (geometrically linear and non-linear) in a system of curvilinear coordinates, he has designed mathematical models and their solution algorithms connected with the optimization problems and analysis of geometrically and physically non-linear structures [183-189].

S. Kalanta has investigated the connections of variational principles of deformable body mechanics [190], has fixed these principles' mathematical expressions by which the possible discontinuities of displacement functions are taken into account [191]. These expressions have allowed to produce dual formulations for analysis and optimization of elastic-plastic plates and shells; these formulations, in their turn, made possible to define the lo- 
wer and upper values of the optimized parameters [192195]. In the analysis of plates, shells and similar structures, the yield conditions are ussually checked at the nodes of finite elements. By combining ingeniously the methods of collocation and finite elements, S. Kalanta has suggested a generalised integral discrete expression of the yield condition $[192,193]$. He has shown that the usual nodes yield conditions and earlier suggested element yield conditions [113-116] are particular cases of this general integral yield condition. S. Kalanta has improved the mathematical models formed by A. Čyras for optimizing the elastic-plastic structures with limiting displacements [196]. The investigations into computing structures by the equilibrium finite element method are generalised in the articles [197, 198].

Almost all scientists of the Dept of Structural Mechanics were engaged in developing eagerly new algorithms for solving problems of elastic-plastic system analysis and optimization (it is characterised in section 3.7), solved problems and by using such numerical experiments specified the research conclusions and demonstrated the advantages of the theory and methods developed.

At the Dept of Structural Mechanics and also under the influence of A. Čyras' ideas Prof A. Borkauskas (Borkowski) has matured; he left for Polish Academy of Sciences and works efficiently now in both optimization, robototechnics and other latest scientific trends [199, 200].

In this Dept of Structural Mechanics (also under the atmosphere of A. Čyras' conceptions), the independent research origins of some scientists of the Dept of Strength of Materials (of VGTU) can be found: alongside A. Čyras the displacement limitation in problems of elasticplastic framed structures optimization was introduced by Prof A Čižas, the limited loading of rigid-plastic plates using the finite element method by Assoc Prof B. S. Mažuolis (1934-1989), the optimization in case of movable loading by Assoc Prof K. Vislavičius, the conditions of finite element yielding by Prof $R$. Kačianauskas.

A distinguished element of research by $\mathrm{A}$. Čižas and his disciples is a linear strain-hardening material. For the analysis and optimization of structures made of this material extreme principles are applied, mathematical models are formulated, solution algorithms are developed following a beaten path of A. Čyras. The first applications of this material for optimizing were associated by A. Čižas with beams and frames of restricted displacements [53], and together with V. Kamaitis also including plates discretized by the finite element method [121]. A. Čižas together with S. Stupak moved away from perfectly plastic hinge concept (which embraces the largest part of research by A. Čyras and his disciples) not only by introducing a new material model but also choosing a real (instead of perfect) shape of bar cross-section, combining optimal framed structures of real set of cross-sections $[201,202]$. M. Šukšta was engaged in analysing variable loading optimization problems for linear strainhardening material beams $[126,130]$. Supervised by
A. Čižas, investigators D. Djankarashvili, J. Medzvieckas, A. Komka dealt with problems of structural analysis and optimization [128, 203, 204]. K. Vislavičius started applying successfully optimization methods for solving material mechanics problems, etc $[205,206]$.

A new stage of investigating deformable and other systems was started by $R$. Kačianauskas. Taking use of euristic principles, he formulated common strategies of multilevel modelling of beams and shells and have generalised these investigations in articles [207, 208] and a monograph [209]. The models of beams and shells are regarded here as complicated multilevel hierarchical systems consisting of complex discrete elements and at different modelling levels the usual procedures of finite element method are applied. R. Kačianauskas and his disciples have enlarged the application of these methods [210-219, etc].

A. Čyras, though he did not discuss the aspects of cyclic strength and failure mechanics, stimulated and supported the experimental and theoretic investigations of this trend. Thanks to his partly support, a good experimental basis was installed adjoining the Dept of Strength of Materials; it has enabled V. Leonavičius, A. Krenevičius, etc. to perform numerous investigations [220-229] (some of them are generalised in the Habilitation work [224]) and conditions have appeared for a Laboratory of Strength Mechanics of a high research capacity. The laboratory performing accredited complicated structural element tests starts to combine them with those theoretical investigations which roots can be found in A. Čyras' and his disciples' endeavours.

The third institution of VISI which has enlarged especially energetically the application of programming for optimizing structures was the Dept of Applied Mathematics and Mechanics administered by Prof D. Maciulevičius (1928-1998). A prominent feature of its optimizational investigations was a perfectly elastic material and synthesis of elastic systems [230-232, etc]. A. Maciulevičius' activities connected with initiating and shaping the computational mechanics in Lithuania represented an essential support for optimizational research which was founded and developed by A. Čyras. The Department was not only a pioneer in informatics, computer programming and the latest computational methods for teaching students, but also an efficient performer of complex research technical projects according to the orders of large research organisations ("Cryogenmash", "Atommash", etc) of the former USSR: from dynamical analysis of disk memory devices for computers up to an optimization of large truss-plate structures for cryogenic equipment.

In recent time the successor of the traditions and research deeds the Dept of Engineering Mechanics guided by Prof R. Belevičius shows a still stronger inclination for computational mechanics. The investigations by $R$. Belevičius (started under the influence of D. Maciulevičius) are devoted to the application of computational algebra to finite element method [233] (they are genera- 
Table 6. The first researchers' studies abroad (1967-1991)

\begin{tabular}{|l|l|l|}
\hline \multicolumn{1}{|c|}{ Scientist } & \multicolumn{1}{c|}{ Country } & \multicolumn{1}{c|}{ Date } \\
\hline A. Borkauskas & Poland & $1967-1968$ \\
\hline R. Baronas & Poland & 1971 \\
\hline R. Karkauskas & Poland & 1975 \\
\hline J. Atkočiūnas & Poland & $1979-1980$ \\
\hline J. Nagevičius & France & 1979 \\
\hline S. Stupak & Italy & $1981-1982$ \\
\hline M. Šukšta & Germany & $1984-1985$ \\
\hline R. Kačianauskas & Germany & 1985 \\
\hline R. Belevičius & Denmark & $1991-1992$ \\
\hline
\end{tabular}

lized in the monograph [234]) and to optimization [235238]. Prof R. Baušys is investigating the applied strategies of generating the finite element network of structural mechanics, etc [239-242]. Other recent investigations of the Department are connected with developing finite elements for plates and shells.

The ideas propagated by A. Čyras have been accepted and developed in other research institutions as well, first of all at Lithuanian universities (his disciples L. Lindišas, V. Šimkūnaitè). Referring to A. Čyras' publications, Prof P. Aliavdin successfully performed investigations in structural optimization at Belorussian Polytechnic Institute (the researcher works now in Poland, at the Uniwersytet Zielonogórski).

Relations of Lithuanian researchers with foreign research institutions, poor at the beginning (Table 6), are developed nowadays. The work of formulating and managing the problems of structural mechanics in Lithuania are coordinated by Lithuanian Association of Computational Mechanics established in 1991; the first chairman of the Association was Prof D. Maciulevičius, now Prof R. Belevičius presides over it. The Association organises seminars, maintains relations with analogous institutions of foreign countries (it is a member of Nordic Association for Computational Mechanics). Prof R. Kacianauskas is member of International Association of Computational Mechanics (in 2001 he was elected member-expert of Lithuanian Academy of Sciences).

\section{Closing remarks}

The stream of scientific research by A. Čyras, his disciples and collaborators guided by him was fairly consolidated, namely optimization of deformable structures; the methods of almost all investigations are based on the theory of mathematical programming (and especially on the duality theory); the reliability of theoretical investigation results was being checked by computational experiments (which required much effort and excellent skills of work with computers). Therefore it cannot perhaps be exaggerated too say that thanks to A. Cyras' research activities the Lithuanian school of optimizational structural mechanics has been developed. Moreover, an im- portant aspect is that the stream of research has not relaxed when its initiator moved off. On the contrary, new investigating efforts, tightened relations with research institutions abroad, more efficient computing technologies allow to enrich year after year the investigations with more considerable results, and thus new trends of computational mechanics come into being.

When taking a glance from the present high positions of the structural mechanics as well as the applied mathematics, some research results published in the middle of the last century (especially those dealing with the optimization of framed structures) may seem to be modest. However, the possibilities of those times should not be forgotten (poor computational technology, extremely restricted ties with foreign countries) as well as the fact that the practice and traditions of research on structural mechanics almost did not exist. The work was proceeding step by step and every step was larger and steadier than the previous ones.

After all it was not an easy matter for Lithuanian research results to win a larger recognition. A. Čyras as an experienced organiser, a skilled manager (though with no special managerial education) understood how important is the recognition by other scientists not only for the researchers themselves but also for their research environment, the investigation basis. At the very outset of the investigations into optimizational problems of structural mechanics he gathered in 1969 in Vilnius, using his acquaintances (not numerous enough at that time), researchers from all the USSR who began to take some interest in the application of mathematical programming to the optimization of structures $[243,19]$. In this way a foundation was laid for the situation that Vilnius city during two decades became a definite centre of this trend of investigations in the USSR. At the same time it has predetermined some help for the research and the opportunities to get consultations of prominent scientists of mechanics and mathematicians in Russia, Ukraine and from time to time to go abroad (mostly to the countries of Eastern Europe, see Table 6). An obstacle for a wider recognition was also the fact that almost all research results had to be published in issues in Russian which are not accessible to Western scientists up to now.

Prof Aleksandras Čyras deeply felt the poetical beauty of perfect mathematical expressions, mathematically expressed statements (not without reason he had a musical education and in his youth he was even head of popular music companies). Therefore he urged the disciples to strive for a really harmonious expression of mathematical models and, having noticed an ingraceful formula, suspected them of the possibility of making mistakes. Striving instinctively for the harmony of investigations, he himself sometimes used to make mistakes. For instance, being engaged in the development of mathematical models for a locking material he tried to regard an elastic locking material as a mirror reflection of elastic perfectly plastic material; such a point of view has not done harm to the analysis of monotonic loading impact, 
but resulted in unreal statements concerning the case of variable loading (stresses cannot accumulate in a locking material in the same way as the strains do in a plastic material).

Sometimes doubts arise as to the practical advantages of the optimization problems formulated by structural mechanics (because these problems loose touch with real design of structures). Because the criterion of optimality represents often the volume of structural elements, the object functions of the problems do not reflect other structure production expenditures and it not always rational to manufacture such a minimal volume structure. Nevertheless, the optimizational investigations in structural mechanics are developing and alongside the undoubtedly valuable theoretical results (especially when the mathematical apparatus and computing technologies constantly are improved) the results with a distinguished practical sense appear. It is also important that the search for new solution algorithms of complex optimizational problems (though extremely theoretized) often results in developing more flexible methods for solving problems of analysis - problems of stresses and strains determination. It is always a pressing problem for those who design structures.

Harmonious combination of mathematical programming and optimization theory together with fundamental principles of mechanics helped A. Cyras and his colleagues to demonstrate the possibilities of research in contemporary structural mechanics, to tie constant development of these possibilities. Aleksandras Čyras, with his purposeful research, with educating a large number of researchers and with higher technical education development in Vilnius, deserves a honourable place among Lithuanian scientists.

\section{References}

1. Klimavičius V. K. Vasiliauskas 1879-1957 (in commemoration of the $90^{\text {th }}$ anniversary of the birth). Lithuanian Proceedings in Mechanics (Lith. Proc. in Mech.), 1969, No 1(4), Vilnius, p. 5-8 (in Russian).

2. Klimavičius V. Development of structural mechanics in Lithuanian SSR during 25 years (1940-1965). Stroitelnaja mechanika, Vilnius: Mintis, 1966, p. 5-9 (in Russian).

3. Krutinis A. Development of structural mechanics in Lithuania in the period 1922-1997. Proceedings of $5^{\text {th }}$ International Conference "Modern Building Materials, Structures and Techniques", Vol 2, Vilnius: Technika, 1997, p. 219-231.

4. Žiliukas A. (ed.). Department of deformable solids 19201995. Kaunas: Technologija, 1995. 24 p. (in Lithuanian).

5. Atkociūnas J., Krutinis A. 75 years to Department of structural mechanics. Mokslas ir technika, 1997, No 5, Vilnius, p. 30-31 (in Lithuanian).

6. Krutinis A., Atkočiūnas J. Development of structural mechanics in Vilnius. Development of technical sciences in Lithuania. Proceedings of science historians conference
(Vilnius, 7 May, 1998). Vilnius: Technika, 1998, p. 162 172 (in Lithuanian).

7. Krutinis A., Atkočiūnas J. Kazimieras Vasiliauskas - pioneer of structural mechanics manuals in Lithuanian (120-th birth anniversary). Development of technical sciences in Lithuania. Proceedings of science historians conference (Vilnius, 22 Sept., 1999). Vilnius: Technika, 1999, p. 18-27 (in Lithuanian).

8. Krutinis A., Atkočiūnas J. Structural mechanics in technical faculties of Lithuanian universities during 1922-2000. Development of technical sciences in Lithuania. Proceedings of science historians conference Vilnius, 24-25 Oct., 2000). Vilnius: Technika, 2000, p. 139-154 (in Lithuanian).

9. Deltuva J., Elzbutas H., Vainiūnas P. Development of structural research and studies in Lithuanian universities. Kaunas: Technologija, 2000. 294 p. (in Lithuanian).

10. Fliotovienè R. Aleksandras Čyras. Bibliography. Vilnius: Technika, 1997. 27 p. (in Lithuanian).

11. Vasiliauskas K., Aukštakalnis P., Baušys J., Čyras A., et al. Strength of materials. Vilnius: State political and scientific publishing house, 1959. 687 p. (in Lithuanian).

12. Atkočiūnas J., Krutinis A. Academician Aleksandras Čyras as the pioneer of optimizational structural mechanics in Lithuania. Statyba (Civil Engineering), 1997, No 1(9), Vilnius: Technika, p. 6-10 (in Lithuanian).

13. Atkociūnas J., Krutinis A. Acad. A. Čyras - a founder of optimizational structural mechanics. Mokslas ir technika, 1997, No 2, Vilnius, p. 14-15 (in Lithuanian).

14. Vilnius Civil Engineering Institute. Vilnius: Mintis, 1977. $131 \mathrm{p}$.

15. Čyras A. Methods of mathematical programming for analysis of elastoplastic one-dimensional systems. Kaunas: Kaunas Polytechnical Institute, 1965. 26 p. (in Russian).

16. Čižas A. Development of optimizational structural mechanics in Vilnius. Lietuvos mokslas, Vol 4, Vilnius, 1996, p. 120-122 (in Lithuanian).

17. Atkočiūnas J., Čižas A. Bibliography of application of mathematical methods in optimizational problems of structural mechanics performed in Lithuanian higher education institutions (up to 1 April, 1971). Lith. Proc. in Mech., 1971, No 1(8), Vilnius, p. 119-130 (in Russian).

18. Kamaitis V. Bibliography of works, performed and published by staff of Vilnius Civil Engineering Institute structural mechanics department during 1971-1975. Lith. Proc. in Mech., 1976, No 1(16), Vilnius, p. 115-124 (in Russian).

19. Čižas A. Structural mechanics optimizational problems in the Vilnius Civil Engineering Institute. Lith. Proc. in Mech., No 27, Vilnius, 1984, p. 5-12 (in Russian).

20. Čyras A. Methods of linear programming for calculations of elastoplastic structures. Leningrad: Strojizdat, 1969. 199 p. (in Russian).

21. Čižas A. "Lithuanian Proceedings in Mechanics" in 19671994. Statyba (Civil Engineering), 1997, No I(9), Vilnius: Technika, p. 11-13. 
22. Čižas A., Čyras A., Maciulevičius D. Optimization problems of structural mechanics. First Baltic-Scandinavian Symposium of Mechanics (Riga, 17-21 Sept., 1990). Riga, 1990, p. 14.

23. Atkočiunnas J. List of research works of the Structural mechanics laboratory in the Vilnius Civil Engineering Institute. Vilnius, 1971. 20 p. (in Russian).

24. Čižas A., Karkauskas R. Summaries of main programmes for design of deformable bodies elaborated in the Department of structural mechanics and that of Structural mechanics laboratory. Vilnius, 1975. 12 p. (in Russian).

25. Čyras A., Karkauskas R., Atkočiūnas J., Kalanta K., et al. Elaboration of structural design, algorithms, PC programmes and recommendations for applications in civil engineering with regard to plastic strains and various types of loads. Vilnius, 1985. 208 p. Research report. 19831985. 208 p. (in Russian, manuscript)

26. Čižas A. Bibliography. Vilnius: Technika, 1999. 42 p. (in Lithuanian).

27. Atkočiūnas J. Professor Algirdas Čižas as famous scientist and educator. Statyba (Civil Engineering), $\mathrm{Vol} \mathrm{V}, \mathrm{No} 3$, Vilnius: Technika, 1999, p. 161-165.

28. Čyras A. Duality in the structural mechanics, elastic and plastic theory problems. Lith. Proc. in Mech., 1968, No 2(3), Vilnius, p. 34-54 (in Russian)

29. Cyras A. Duality in the structural mechanics, elastic and plastic theory problems (continued). Lith. Proc. in Mech., 1969. No 1(4), Vilnius, p. 9-25 (in Russian).

30. Ministry of higher education of the USSR. Structural mechanics syllabus for structural engineering study programmes. Moscow, 1985. 14 p. (in Russian).

31. Čyras A., Borkauskas A., Karkauskas R. Theory and methods of elastoplastic structures. Leningrad: Strojizdat, 1974. 280 p. (in Russian)

32. Cyras A. Mathematical analogues of the perfectly elastic system load optimization problems. Lith. Proc. in Mech., 1973, No 1(12), Vilnius, p. 5-11.

33. Cyras A. Mathematical analogues of the linear-elastic body optimization problems. Lith. Proc. in Mech., 1974, No I2(14-15), Vilnius, p. 5-27.

34. Čras A. On optimizational theory in mechanics of deformable solids. Vilnius, 1974. 30 p. (in Russian).

35. Čyras A. Optimization problem of deformed solids and their mathematical models. Vilnius, 1979. 15 p. (in Russian).

36. Cyras A. Optimization theory in the design of elastoplastic structures. Structural optimization: CISM courses and lectures, No 237, Berlin, Springer-Verlag, 1975, p. 81-150.

37. Čyras A. Optimization problems in theory of plasticity. Duality and complementarity in mechanics of solids, Wroclaw, 1979, p. 95-172.

38. Cyras A. Mathematical models for the analysis and optimization of elastoplastic structures. Vilnius: Mokslas, 1982. 112 p. (in Russian with English summaries).
39. Čyras A., Atkočiūnas J. The analysis of perfectly elasticplastic body under cyclic load. Lith. Proc. in Mech., 1970, No 2(7), Vilnius, p. 31-43 (in Russian).

40. Čyras A., Atkočiūnas J. The design of perfectly elasticplastic body under variable repeated loading. Lith. Proc. in Mech., 1971, No 2(7), Vilnius, p. 71-78 (in Russian).

41. Borkowski A., Atkočiūnas J. Optimal Design for Cyclic Loading. Optimization in structural design, IUTAM, Symposium, Warsaw, 1973. Springer-Verlag, 1975, p. 432-440.

42. Cyras A. Mathematical models for the analysis and optimization of elastoplastic structures. Chichester: Ellis Horwood Limited, 1983. $121 \mathrm{p}$

43. Čižas A. On solving some nonlinear stochastic programming problems. Lith. Proc. in Mech., 1972, No I(10), Vilnius, p. 15-20 (in Russian).

44. Čižas A. Strain or displacement constraints in elasto-plastic analysis in case of repeated variable loading and linear state of stress. Lith. Proc. in Mech., No 19, Vilnius, 1978, p. 24-33.

45. Atkočiūnas J., Borkowski A., König J. A., Improved bounds for displacements at shakedown. Comput. Methods Appl. Mech. Eng., No 28, 1981, p. 365-376.

46. Atkočiūnas J. Design of elastoplastic systems under repeated loading. Vilnius: Science and encyclopaedic publishing house, 1994. 148 p. (in Russian).

47. Fliotoviene R. Application of finite element method to the analysis of linearly locking systems. Lith. Proc. in Mech., No 32, Vilnius, 1990, p. 44-54 (in Russian)

48. Čyras A., Fliotoviene R. Theory of locking. Vilnius: Technika, 1995. 76 p. (in Russian).

49. Čyras A., Dulman V. Mathematical analogues of the optimization problems on the steady creep conditions. Lith. Proc. in Mech., 1973, No I(12), Vilnius, p. 13-24 (in Russian).

50. Čižas A., Čyras A. Linear programming application to elasto-plastic structures in view of limited deformation (serviceability). Stroitelnaja mekhanika, Vilnius, 1966, p. 24 41 (in Russian).

51. Baronas R., Cyras A. Dual problems in deformation analysis of elastic-plastic one-dimensional systems. Lith. Proc. in Mech., 1967, No 1, Vilnius, p. 61-75 (in Russian).

52. Čižas A., Čyras A. Analysis of elastic-plastic structura] design considering limited deformations. Lith. Proc. in Mech., 1967, No l, Vilnius, p. 102-114 (in Russian).

53. Čižas A. On design of elastoplastic strainhardening onedimensional structures. Stroitelnaja mekhanika $i$ raschet sooruzhenij, 1973, No 2, p. 16-20 (in Russian).

54. Čižas A. On optimal design of strainhardening structures. Optimization in structural design: IUTAM Symposium, Warsaw, 1973. Springer-Verlag, 1975, p. 555-563.

55. Šukšta M., Čižas A. Mathematical analogue for design of linear strainhardening beam. Lith. Proc. in Mech., No 24, Vilnius, 1982, p. 5-13 (in Russian). 
56. Atkočiūnas J. Mathematical analogues of optimization problems of elastic plastic systems under displacement restriction. Lith. Proc. in Mech., No 26, Vilnius, 1983, p. $58-64$.

57. Čyras A. Mathematical analogues of optimization problems of elastic plastic systems under displacement restriction. Lith. Proc. in Mech., No 27, Vilnius, 1984, p.13-20.

58. Čyras A. Extremum principles and optimization problems for linearly strain hardening elastoplastic structures. Prikladnaja mekhanika, Vol 22, No 4, 1986, p. 89-96 (in Russian).

59. Čyras A. and Norkus A. On optimization of elastoplastic systems under random loading. Mechanics Research Communications, Vol 20(4), 1993, p. 293-299.

60. Rejtman M. Foreign books on optimal design. Stroitelnaja mekhanika $i$ raschet sooruzhenij, 1976, No 4, p. 62-64 (in Russian).

61. Gerard G. Minimum weight analysis of compression structures. New York Univ. Press., 1956.

62. Mróz Z. On the problem of minimum weight design. Brown University, 1960.

63. Cox H. L. The design of structures of least weight. Pergamon Press, 1965.

64. Leśniak Z. Methoden der Optimierung von Konstruktionen. Köln: Ernst und Sohn, 1970.

65. Hupfer P. Optimierung der Baukonstruktionen. Berlin: VEB, 1970.

66. Armand J.-L. Application of the theory of optimal control of distributed-parameter system to structural optimization. PhD. Thesis. Stanford univ. Stanford, 1971.

67. Prager W. Introduction to structural optimization. Intern. Centre Mech. Sci. Udine, 1974.

68. Cohn M. Z. and Maier G. (eds.). NATO Advanced Study Institute, University of Waterloo, 1977, Proceedings. Engineering plasticity by mathematical programming. New York: Pergamon Press, 1979. $648 \mathrm{p}$.

69. Maier G. and Munro J. Mathematical Programming Applications to Engineering Plastic Analysis. Applied Mechanics rewiews, Vol 35, No 12, 1982, p. 1631-1643.

70. Čyras A. Optimization theory in limit analysis of a solid deformable body. Vilnius: Mintis, 1971. 124 p. (in Russian with English summaries).

71. Čyras A., Borkauskas A. Dual problems of optimization in continuum limit equilibrium theory. Stroitelnaja mekhanika i raschet sooruzhenij, 1969, No 4, Moscow, p. 5-10 (in Russian).

72. Collins J. F. An optimum loading criterion for rigid-plastic materials. J. Mech. Phys. Solids, Vol 16, No 2, 1968.

73. Koiter W. T. General theorems for elastic-plastic solids. Progress in Solid Mechanics, Amsterdam, 1960, p. 165221.

74. Cyras A. Elastic-plastic body optimization theory in the case of movable load. Lith. Proc. in Mech., No 19, Vilnius, 1978, p. 5-23 (in Russian).
75. Gokhfeld D. A., Cherniavsky O. F. Limit analysis of structures at thermal cycling. Sijthoff \& Noordhoff, 1980. 537 p.

76. Borkowski A., Kleiber M. On numerical approach to shakedown analysis of structures. Comput. Methods Appl. Mech. Eng, No 22, 1980, p. 101-119.

77. König A., Maier G. Shakedown analysis of elastoplastic structures: a review of recent developments. $J$. Nuclear Engineering Design, Vol 66, 1981, p. 81-95.

78. Ikrin V. A. The prognosis of possible states of structures adapting to unregulated static actions. Irkutsk: Irkutsk University Publishers, 1986. 160 p. (in Russian)

79. König J. A. Shakedown of Elastic-Plastic Structures. Warsaw and Amsterdam, 1987. 214 p.

80. Procenko A. M. Extremum boundary problems for an elastic-plastic body. Izvestija Akademii nauk SSSR. Mekhanika tverdogo tela, 1974, No 1 (in Russian).

81. Borkauskas A., Cyras A.. The elastic-plastic analysis of plates by linear programming. Lith. Proc. in Mech., 1967. No l, Vilnius, p. 43-60 (in Russian).

82. Borkauskas A., Čyras A. Minimum weight design of elastic-plastic plates in terms of linear programming. Lith. Proc. in Mech., 1968, No 1(2), Vilnius, p. 136-150 (in Russian).

83. Borkauskas A., Čyras A. Duality in nonlinear limit analysis problems. Lith. Proc. in Mech., 1968, No 2(3), Vilnius, p. 55-67 (in Russian).

84. Nagevičius J., Čyras A. Determination of the limit loading of shallow cylindrical shells by mathematical programming. Lith. Proc. in Mech., 1968, No 2(3), Vilnius, p. 68-78 (in Russian).

85. Nagevičius J., Čyras A. Analysis and design of cylindrical shells of material with different tensile and compressive yield strength. Lith. Proc. in Mech., 1970, No 1(6), Vilnius, p. 25-51 (in Russian).

86. Krutinis A., Čižas A. A way of the optimal load distribution on elastic-plastic one-dimensional systems with limited deformations. Lith. Proc. in Mech., 1970, No 2(7), Vilnius, p. 63-74 (in Russian).

87. Baublys P., Cypinas I. The use of the gradient method for the synthesis of elastic systems subjected to buckling. Lith. Proc. in Mech., 1969, No 1(4), Vilnius, p. 70-61 (in Russian).

88. Karkauskas R., Čyras A. Non-linear problems of the rigidplastic shallow spherical shell analysis. Lith. Proc. in Mech., 1970, No 2(7), Vilnius, p. 45-62 (in Russian).

89. Karkauskas R., Čyras A. Non-linear problems of rigid-plastic spherical shells design. Lith. Proc. in Mech., 1971, No 1(8), Vilnius, p. 93-104 (in Russian).

90. Borkauskas A., Karkauskas R. On numerical aspects of the mathematical programming application to limit design of plates and shells. Lith. Proc. in Mech., 1971, No 2(9), Vilnius, p. 47-54 (in Russian).

91. Atkočiūnas J., Karkauskas R., Čyras A. The finite element method in non-linear problems of the design of elasticplastic circular plates under variable-repeated loading. Lith. 
Proc. in Mech., 1972, No 2(11), Vilnius, p. 75-91 (in Russian).

92. Kalanta S., Cyras A. Finite element method in the analysis problems of rigid-plastic cylindrical shells. Lith. Proc. in Mech., 1972, No 2(11), Vilnius, p. 37-48 (in Russian).

93. Kalanta S., Atkočiūnas J., Mažuolis B., Čyras A. Nonlinear problems of the rigid-plastic thin rectangular plates analysis. Lith. Proc. in Mech., 1972, No 2(11), Vilnius, p. 67-74 (in Russian).

94. Kalanta S., Nagevičius J., Čyras A. Analysis and design of shallow cylindrical shells by nonlinear programming methods. Lith. Proc. in Mech., 1972, No 1(10), Vilnius, p. 35-47 (in Russian).

95. Čyras A., Kalanta S. Optimal design of cylindrical shells by the finite element technique. Int. J. Mechanics Research Communications, 1974, No 3, p. 125-130.

96. Karkauskas R., Atkočiūnas J. Finite element equivalent of the spherical. Lith. Proc. in Mech., 1976, No I(16), Vilnius, p. 91-103 (in Russian).

97. Čyras A., Karkauskas R., Atkočiūnas J. Optimization of rigid plastic shell by the finite element method. IASS International Conference on light weight shell and space structures for normal and seismic zones (Alma-Ata, 1977). Mir Publishers, 1977, p. 37-41.

98. Kalanta S., Atkočiūnas J. Optimization of elasto-plastic round plates under variable repeated loading by finite element method. Lith. Proc. in Mech., 1977, No 1(17), Vilnius, p. 78-85 (in Russian).

99. Kalanta S., Karkauskas R., Atkociūnas J. Problems of the optimization of the elastic-plastic spherical shells under variable-repeated-loading. Lith. Proc. in Mech., 1977, No 1(17), Vilnius, p. 86-93 (in Russian).

100. Borkauskas A., Čyras P., Karkauskas R. On the solution of a plastic-locking thick-walled tube. Lith. Proc. in Mech., 1977, No 1(17), Vilnius, p. 21-33 (in Russian).

101. Čyras A., Vislavičius K. Optimization of elastic-plastic structure under movable loading. Mechanics Research Communications, Vol 2, No 4, 1975, p. 181-185.

102. Vislavičius K., Atkočiūnas J. Optimization of elastic-plastic plates under movable loading. Lith. Proc. in Mech., 1977, No 1(17), Vilnius, p. 71-77 (in Russian).

103. Skaržauskas V., Čyras A. Optimal design of the elastoplastic arches in case of movable load. Lith. Proc. in Mech., No 20, Vilnius, 1979, p. 117-123.

104. Kalanta $\mathrm{S}$. The equilibrium finite element method in mechanics of elastic solids. Mathematical analogue. Lith. Proc. in Mech., No 19, Vilnius, 1978, p. 42-55 (in Russian).

105. Kalanta $S$. The equilibrium finite element method in mechanics of elastic solids. Force and displacement methods. Lith. Proc. in Mech., No 20, Vilnius, 1979, p. 35-44 (in Russian).

106. Kalanta S. Calculus of elastic pin-jointed and framed plane structures by the finite element technique. Lith. Proc. in Mech., No 26, Vilnius, 1983, p. 78-94 (in Russian).
107. Kalanta S. Problems of the optimal design of elastic-plastic plates and shells. Lith. Proc. in Mech., No 20, Vilnius, 1979 , p. 57-68 (in Russian).

108. Atkočiūnas J. On designing of elastic-plastic plates of the smallest volume by the finite element methods. Lith. Proc. in Mech., No 20, Vilnius, 1979, 69-74 (in Russian).

109. Prusakovas L., Atkočiūnas J., Kačianauskas R. Mathematical analogues of plane stress optimization problem by equilibrium finite element method in plastic stage. Lith. Proc. in Mech., No 24, Vilnius, 1981, 14-19 (in Russian).

110. Kačianauskas R., Kalanta S., Čyras A. Nonlinear optimization problems of thin-walled plastic finite-element structures. Lith. Proc. in Mech., No 26, Vilnius, 1983, p. 6577 (in Russian).

111. Kalanta S. Dual mathematical models of rigid-plastic systems optimization problems. Stroitelnaja mekhanika i raschet sooruzhenij, 1982, No 3, 1983, p. 11-15 (in Russian).

112. Kačianauskas R. Iterative solution of design problems of elastic-plastic minimum volume shells. Lith. Proc. in Mech., No 27, Vilnius, 1984, p. 49-54 (in Russian).

113. Kačianauskas R., Kalanta S., Čyras A. The finite element yield criterion for shallow shells of double curvature. Lith. Proc. in Mech., No 20, Vilnius, 1979 p. 75-82 (in Russian).

114. Kacianauskas R., Kalanta S., Čyras A. Determination of the yield function matrices for the finite elements of plates and shells. Lith. Proc. in Mech., No 23, Vilnius, 1981, p. 51-64 (in Russian).

115. Kačianauskas R., Kalanta S., Čyras A. Determination of the yield function matrices for the curved finite elements of thin shells and plates. Lith. Proc. in Mech., No 24, Vilnius, 1981, p. 44-55 (in Russian).

116. Kačianauskas R., Kalanta S., Čyras A. Yield conditions of a finite element in design problems of elastoplastic plates and shells. Stroitelnaja mekhanika $i$ raschet sooruzhenij, 1982, No 5, p. 6-10.

117. Kačianauskas R., Čyras A. The integral yield criterion of finite elements and its application to limit analysis and optimization problems of thin-walled elastic-plastic structures. Computer Method in Applied Mechanics and Engineering, No 67, 1988, p. 131-147.

118. Valiukonis P., Čižas A. Yield conditions in asymmetrical I-section acted by axial force and bending moment. Lith. Proc. in Mech., 1972, No 2(11), p. 61-66 (in Russian).

119. Kamaitis V., Čižas A. The equilibrium finite element method in structural mechanics. Lith. Proc. in Mech., 1973, No 1(12), Vilnius, p. 105-114.

120. Kamaitis V., Čižas A. Singleparametric design of strainhardening plates by equilibrium finite element method. Lith. Proc. in Mech., 1973, No 2(13), Vilnius, p. 64-73.

121. Kamaitis V., Čižas A. The plate optimal design problem in the case of isotropic and kinematic strainhardening. Lith. Proc. in Mech., 1974, No 1-2 (14-15), Vilnius, p. 83-93 (in Russian). 
122. Čižas A. An algorithm for design of the elasto-plastic frame with due regard to the form of cross sections. Lith. Proc. in Mech., 1976, No 1(16), Vilnius, p. 104-113 (in Russian).

123. Stupak S., Čižas A. A Computing experiment of the framed structure design with due regard to plastic strain spreading. Lith. Proc. in Mech., 1977, No 1(17), Vilnius, p. 94 99 (in Russian).

124. Čižas A. Algorithm of discrete programming for optimization of framed structures made of some bar set. VIII Internationaler Kongress über Anwendungen der Mathematik in den Ingenieur-Wissenschaften: Berichte, 1 . Weimar, 1978, p. 171-176 (in Russian).

125. Matulioniené J., Čižas A. Mathematical equivalent of the design problem of the elasto-plastic linear strain-hardening pin-jointed system under repeated variable loading. Lith. Proc. in Mech., No 22, Vilnius, 1982, p. 71-78 (in Russian).

126. Šukšta M., Čižas A. Optimum distribution of repeated varriable loading on beams made of linear hardening material. Lith. Proc. in Mech., No 22, Vilnius, 1980, p. 7989 (in Russian).

127. Stupak S. Approximation of the law of the elasto-plastic bending when sections of the frame are of any real shape. Lith. Proc. in Mech., No 24, Vilnius, 1982, p. 39-43 (in Russian).

128. Komka A., Čižas A. Determination of the strain state of elastic-plastic bar with tubular cross-section. Lith. Proc. in Mech., No 25, Vilnius, 1982, p. 47-58 (in Russian).

129. Šukšta M. Approximation of plastic deformation distribution in perfectly elasto-plastic girders. Lith. Proc. in Mech., No 29, Vilnius, 1987, p. 44-57 (in Russian).

130. Šukšta M., Čižas A. Determination of optimal repeated variable loading bounds for framed structures. Strojitelnaja mechanika i raschet sooruzhenij, 1983, No 2, p. 6-10 (in Russian).

131. Cyras A. Dual mathematical models of problems for the determination of the stress and strain field of an elasticplastic solid in the shakedown state. Lith. Proc. in Mech., No 21, Vilnius, 1980, p. 9-19 (in Russian).

132. Rimkus L., Čyras A. Determination of the limit temperature changes parameters for elastic-plastic framed systems. Lith. Proc. in Mech., No 24, Vilnius, 1981, p. 20-29 (in Russian).

133. Čyras A., Čiupaila L. Degenerated problems of analysis of elastic-perfectly plastic frames. Lith. Proc. in Mech., No 25, Vilnius, 1982, p. 18-27 (in Russian).

134. Čyras A., Čiupaila L. On determination of displacement bounds for perfectly elastic plastic systems under repeated variable load. Stroitelnaja mekhanika i raschet sooruzhenij, 1984, No 1, Moscow, p. 13-18 (in Russian).

135. Daniūnas A. Equilibrium finite element method in analysis problems of elastic-plastic plates. Lith. Proc. in Mech., No 27, Vilnius, 1984, p. 28-39.

136. Cyras A., Daniūnas A. Mathematical Models for the Analysis and Optimization of Elastic-Plastic Plates and Shells Under Complete Plastic Failure. Proceedings of IUTAM symposium: 1985, Rio de Jeneiro. Springer-Verlag, 1986 p. 345-356.

137. Žukas N., Čyras A., Atkočiūnas J. Non-linear analysis problem of the elastic-plastic circular cylindrical shell. Lith. Proc. in Mech., No 28, Vilnius, 1986, p. 29-44 (in Russian).

138. Brzeziński R., König J. A. Deflection analysis of elasticplastic frames at shakedown. J. Struct. Mech., 1973, 2, p. 211-228.

139. Dorosz S. An upper to maximum residual deflections of elastic-plastic structures at shakedown. Bull. Ac. Pol. Sci Ser. Sci. Techn., 24, 1976, p. 167-174.

140. König J. A., Maier G. Shakedown analysis of elastoplastic structures: a review of recent developments. $J$. Nuclear Engineering Design, Vol 66, 1981, p. 81-95.

141. Atkočiūnas J. On evaluation of deflections of shakedown. Lith. Proc. in Mech., No 23, Vilnius, 1981, p. 77-88 (in Russian).

142. Atkočiūnas J. Algorithms of elastoplastic structural optimization in case of repeated variable load. Soprotivlenie materialov i teorija sooruzhenij, 45, Kiev, 1984, p. 75-77 (in Russian).

143. Atkočiūnas J. Application of finite element method in problems for the evaluation of stress and strain state of elasticplastic solid up to plastic failure. Lith. Proc. in Mech., No 27, Vilnius, 1984, p. 21-27 (in Russian).

144. Čyras A., Atkočiūnas J. Mathematical model for the analysis of elastic-plastic structures under repeated-variable loading. Mech. Res. Comm., Il, 1984, p. 353-360

145. Atkočiūnas J. Mathematical model of elastoplastic system shakedown state analysis problem. Prikladnaja mekhanika, 21, No 6, Kiev, 1985, p. 79-85 (in Russian).

146. Atkočiūnas J. Mathematical model for analysis of elastoplastic system under repeated-variable loading Stroitelnaja mekhanika $i$ raschet sooruzhenij, 1985, No 4, Moscow, p. 28-31 (in Russian).

147. Atkočiūnas J. Determination of residual displacements at shakedown. Lith. Proc. in Mech., No 28, Vilnius, 1986, p. 16-28 (in Russian).

148. Atkočiūnas J., Kalanta S. Dual finite element in structural shakedown problems. Soprotivlenie materialov $i$ teorija sooruzhenij, 49, Kiev, 1986, p. 61-63 (in Russian).

149. Atkočiūnas J. Local constraints in mathematical models of shakedown structures possible states prognosis problems. Stroitelstvo i arkhitektura, 1990, No 5, Novosibirsk, p. 2427 (in Russian).

150. Atkociunas $J$. The non-linear optimization problems of the load distribution and their solving. Lith. Proc. in Mech, No 32, Vilnius, 1990, p. 27-43 (in Russian).

151. Baušys R., Karkauskas R. Optimum design of elastic-plastic frame under displacement constraints. Lith. Proc. in Mech., No 29, Vilnius, 1987, p. 33-43 (in Russian).

152. Baušys R., Karkauskas R., Čyras A. On algorithm for optimum design of elastic-plastic structures under displacement constraints. Lith. Proc. in Mech., No 31, Vilnius, 1989 , p. 43-53 (in Russian). 
153. Atkočiūnas J. Computer-aided design of elastic-plastic plates and shells. Lith. Proc. in Mech., No 30, Vilnius, 1988 , p. $43-55$ (in Russian).

154. Cyras A. Structural Mechanics. Theory and Algorithms. Moscow: Strojizdat, 1989. 225 p. (in Russian).

155. Cyras A. Structural Mechanics. Vilnius: Mokslas, 1990. 448 p. (in Lithuanian).

156. Karkauskas R., Krutinis A., Atkočūnas J., Kalanta S., Nagevičius J. Structural mechanics. Programmes and solution of problems by PC. Moscow: Strojizdat, $1990.360 \mathrm{p}$. (in Russian).

157. Karkauskas R., Krutinis A., Atkočiūnas J., Kalanta S., Nagevičius J. Solution of structural mechanics problems by computers. Vilnius: Science and Encyclopaedic Publishing House, 1995. 264 p. (in Lithuanian).

158. Krutinis A. Mathematical models for design of elastoplastic structures on deformable ground. Lith. $J$. of Computational Mechanics (Lith. Proc. in Mech., No 33), Vilnius: Technika, 1994 , p. $108-116$

159. Grigusevičius A., Kalanta S., Krutinis A. Analysis of construction on elastic foundation with evaluation of all system dead weight. Statyba (Civil Engineering), Vol VII, No 2, Vilnius: Technika, 2001, p.115-121 (in Lithuanian).

160. Krutinis A. Design theory and methods of structures on elastic foundation. Vilnius: Technika, 2001. 168 p. 26. (in Lithuanian).

161. Skaržauskas V. Atkočiūnas J. Displacement determination of elastic-plastic arches under mobile load. Stroitelstvo $i$ arkhitektūra, 1987, No 3, Novosibirsk, p. 113-115 (in Russian).

162. Karkauskas R., Skaržauskas V., Atkočiūnas J. Extremal principles and problems of elastic-plastic unloading systems. Sbornik nauchnych trudov, Kazan, 1996, p. 93-98 (in Russian).

163. Skaržauskas V., Merkevičiūte D., Atkočiūnas J. Optimization of shakedown elasto-plastic frames loading. Statyba (Civil Engineering), Vol VII, No 6, Vilnius: Technika, 2001, p. 427-434. (in Lithuanian).

164. Rimkus L. The strain state of a framed system under complete plastic failure subjected to variable temperature. Lith Proc. in Mech., No 3l, Vilnius, 1989, p. 20-25 (in Russian).

165. Rimkus L. Design of bar systems under cyclic temperature changes. Lithuanian J. of Computational Mechanics, (Lith. Proc. in Mech. No 33), Vilnius: Technika, 1993, p. 18-25 (in Russian).

166. Kalanta. S., Fliotovienè R. Locking conditions for finite element method. Statyba (Civil Engineering), 1997. No 1(9), Vilnius: Technika, p. 57-65.

167. Norkus A. On reliability-based optimization in rigidplastic frame design. Statyba (Civil Engineering), 1997, No I(9), Vilnius: Technika, p. 78-81 (in Russian)

168. Atkočiūnas $J$. Limit of energy dissipation at shakedown structures. Stroitelstvo i arkhitektūra, 1993, No 3, Novosibirsk, p. 89-92 (in Russian).
169. Atkočiunas J. New Approach to the Koiter's Inequality for shakedown, Mechanics Research Communications, Vol 20, No 4, 1993, p. 301-308.

170. Atkočiūnas J. State analysis of discrete structures at shakedown under repeated loadings. Lithuanian J. of Computational Mechanics, (Lith. Proc. in Mech. No 33), Vilnius: Technika, 1994, p. 46-55.

171. Atkočiūnas J., Norkus A. Method of fictitious system for evaluation of frames shakedown displacements. Computer and Structures, 50, No 4, 1994, p. 563-567.

172. Atkočiūnas J. Distorsion in structural mechanics. Statyba (Civil Engineering), 1995, No I(l), Vilnius: Technika, p. 324 (in Russian).

173. Atkočiūnas J. Holonomic analysis for displacements at shakedown via quadratic programming. Mechanika, 1995, No 2, Kaunas: Technologija, p. 18-23.

174. Atkočiūnas J. Energetische Grenzen des Einspielzustandes elastoplastischer Konstruktionen. Wiss. Z. Hochsch. Archit. Bauwes, 41 6/7, Weimar, 1995, p. 183-185.

175. Atkočiūnas J. Kuhn-Tucker conditions in shakedown problems. Statyba (Civil Engineering), 1996, No I(5), Vilnius: Technika, p. 14-28 (in Russian)

176. Atkočiūnas J. Quadratic programming for degenerate shakedown problems of bar structures. Mechanics Research Communications, Vol 23, No 2, 1996, p. 195-203.

177. Atkočiūnas J., Norkus A. and Rimkus L. Distorsion in mechanics of elastic and elastic-plastic frames. Computers and Structures, Vol 62(5), 1997, p. 861-864.

178. Atkočiūnas J. Energy interpretation of complementarity conditions in shakedown problems. Statyba (Civil Engineering), 1997, No 1(9), Vilnius: Technika, p. 14-25 (in Russian).

179. 179. Atkočiūnas J. Compatibility equations of strains for degenerate shakedown problems. Computer and Structures, Vol 63, No 2, 1997, p. 277-282.

180. Atkočiūnas J. Mathematical Models of Optimization Problems at Shakedown. Mechanics Research Communications, Vol 26, No 3, 1999, p. 319-326.

181. Chraptovič E., Atkočiūnas J. Role of Kuhn-Tucker conditions in elasticity equations in terms of stresses. Staty $b a$ (Civil Engineering), Vol VI, No 2. Vilnius: Technika, 2000, p. 104-112 (in Russian).

182. Chraptovič E., Atkočiūnas J. Mathematical programming applications peculiarities in shakedown problem. Statyba (Civil Engineering), Vol VII, No 2, Vilnius: Technika, 2001, p. 106-114. (in Russian)

183. Karkauskas R. Dual relations of linear thin general shell theory. Statyba (Civil Engineering), 1997, No 1(9), Vilnius: Technika, p. 66-74

184. Karkauskas R. On geometrically nonlinear structures and analysis. Statyba (Civil Engineering), 1997, No 4(12), Vilnius: Technika, p. 38-43.

185. Karkauskas R. Analysis of non-holonomic behaviour of geometrically nonlinear elastic-plastic framed structures Mechanika, 1997, No 4(11), Kaunas: Technologija, p. 2430. 
186. Karkauskas R. Analysis of geometrically non-linear elastic-plastic framed structures. Statyba (Civil Engineering), Vol IV, No 1, Vilnius: Technika, 1998, p. 36-42 (in Lithuanian).

187. Karkauskas R. Optimization on Geometrically Nonlinear Elastic-Plastic Structures Under Displacement Constraints. Semi-rigid joints in metal and composite structures (Proceedings of international symposium). Warsaw, 2000, p. 319-326.

188. Karkauskas R., Norkus A. On for Design Algorithm Geometrically Nonlinear Elastic-Plastic Structural Optimization Under Displacement Constraints. Mechanika, 2001, No 4 (30), Kaunas: Technologija, p. 50-55.

189. Karkauskas R., Norkus A. Optimization of geometrically nonlinear elastic-plastic structures under stiffness constraints. Mechanics Research Communications, Vol 28, No 5, 2001, p. 505-512.

190. Kalanta S. Relations and transformations of extremum energy principles for deformable body. Statyba (Civil Engineering), 1997, No I(9), Vilnius: Technika, p. 49-56.

191. Kalanta $S$. Variational principles and formulations of the deformable body problems with discontinuities of functions. Mechanika, 1998, No 3(14), Kaunas: Technologija, p. 5-13 (in Russian).

192. Kalanta S. Dual mathematical models of elastoplastic structures analysis problem estimating discontinuity of displacements. Statyba (Civil Engineering), 1995, No 3(3), Vilnius: Technika, p. 5-29 (in Russian).

193. Kalanta S. Mixed and compatible finite elements in the analysis problem of elastoplastic structures. Statyba (Civil Engineering), 1996, No 1(5), Vilnius: Technika, p. 29-43 (in Russian)

194. Kalanta S. The problems of limit load analysis and optimization using equilibrium finite elements. Statyba (Civil Engineering), 1996, No 3(7), Vilnius: Technika, p. 13-23 (in Russian).

195. Kalanta S. Dual mathematical models of limit load analysis problems of structures by mixed finite elements. Statyba (Civil Engineering), 1997, No 2(10), Vilnius: Technika, p. 43-51 (in Russian).

196. Kalanta S. New formulations of optimization problems of elasto-plastic bar structures under displacement constraints. Mechanika, 1999, No 5(20), Kaunas: Technologija, p. 9 16. (in Russian).

197. Kalanta S. One variant of the finite-element method in elasticity theory. International Applied Mechanics, Vol 30 , No 2, 1994, p.148-152.

198. Kalanta $S$. The equilibrium finite elements in computation of elastic structures. Statyba (Civil Engineering), 1995, No I(1), Vilnius: Technika, p. 25-47 (in Russian).

199. Borkowski A. Analysis of skeletal structural systems in the elastic and elastic-plastic ranges. Warszawa - Poznan, 1985. 200 p. (in Polish).

200. Borkowski A. Analysis of skeletal structural systems in the elastic and elastic-plastic ranges. Warszawa: PWN Elsevier, 1988. $200 \mathrm{p}$.
201. Čižas A., Stupak S. Optimal discrete design of elastoplastic sructures. Discrete structural optimization, - SpringerVerlag, 1994, p. 200-208.

202. Čižas A. Behaviour of beams with spreads of plastic strains Lith. J. Of Computational Mechanics (Lith. Proc. in Mech. No 33), Vilnius, 1994, p. 92-98.

203. Dshankarashwili D., Čižas A. Mathematical equivalents of the problems of the prestressed elasto-plastic one-node cable system design. Lith. Proc. in Mech., 1977, No 1(17), p. 62-70 (in Russian).

204. Medzvieckas J., Čižas A. Design of the elastic continuous beam with optimal pliability of supports. Lith. Proc. in Mech., No 28, Vilnius, 1986, p. 72-81 (in Russian).

205. Krenevičius A., Vislavičius K. Increasing fatigue durability of a bolt joint. Statyba (Civil Engineering), Vol VI, No 2, Vilnius: Technika, 2000, p. 262-266 (in Lithuanian).

206. Vislavičius K. General principles of modelling physicalmechanical properties of conglomerates. Statyba (Civil Engineering), Vol VI, No 3, Vilnius: Technika, 2000, p. 175-178 (in Lithuanian).

207. Kačianauskas R., Maciulevičius D., Kutas R. Multicriteria optimization of pin-jointed structures with overall stability constraints. International Journal Numerical Method Engineering, 1992, No 34, p.893-900.

208. Kacianauskas R., Baušys R. Macroelement approach to the analysis of cylindrical shells connected by tape-roller bearings. Computer and Structures, No 54, 2, 1995, p. $247-$ 254.

209. Kačianauskas R. Computer methods in multilevel modelling of beams and shells. Vilnius: Technika, 1995. $395 \mathrm{p}$.

210. Kačianauskas R., Kutas R. Modelling of cryogenic structure under seismic loading. Statyba (Civil Engineering), 1995, No 1(1), Vilnius: Technika, p. 59-75.

211. Kačianauskas R., Žukas N., Paulauskas V. Free-vibration analysis of a sailplane by one-dimensional finite elements. Mechanika, 1995, No 3, Kaunas: Technologija, p. 5-10.

212. Kačianauskas R. Semi-analytically based finite elements and their application to thin-walled beams. Statyba (Civil Engineering), 1995, No 2(2), Vilnius: Technika, p. 3-19.

213. Kačianauskas R., Kupliauskas R., Kudzys A. Modelling of concrete inhomogeneity under uniaxial tension. Mechanika, 1996, No 1(4), Kaunas: Technologija, p. 514.

214. Kačianauskas R., Rutschmann P. Implementation and testing of finite elements for Navier-Stokes equations in the FEMTOOL code. Mechanika, 1996, No 2(5), Kaunas: Technologija, p. 5-15.

215. Kacianauskas R., Argyris J. Semi-analytical finite elements in the higher-order theory of beams. Comput. Methods Appl. Mech. Eng., 1996, No 138, p. 19-72.

216. Kačeniauskas A., Kað̌ianauskas R. Formulation and analysis of boundary conditions for the sluicegate problems. Mechanika, 1997, No 4(11), Kaunas: Technologija, p. 510. 
217. Samofalov M., Kačianauskas R. Investigation of thinwalled column with variable I-section stability using finite element method. Statyba (Civil Engineering), Vol VI, No 2, Vilnius: Technika, 2000, p. 69-75 (in Lithuanian).

218. 218.Stupak E., Kačianauskas R. Application of the adaptive finite element meshes for stress analysis at the concentrator. Mechanika, 2000, No 4(24), Kaunas: Technologija, p. 31-36 (in Lithuanian).

219. Jaras A., Kačianauskas R. Elastic-plastic analysis of bisteel I-section beams. Statyba (Civil Engineering), Vol VII, No 2, Vilnius: Technika, 2001, p. 122-130.

220. Leonavičius M., Šukšta M. The bolt with a crack shakedown estimation by the method of additional load. Statyba (Civil Engineering), 1997, No 1(9), Vilnius: Technika, p. 74-77.

221. Leonavičius M., Krenevičius A. Shakedown and failure of the threaded joints under low cyclic loading. $J$. of Constructional Steel Research, Vol 46, Elsevier, 1998, p. 452453.

222. Leonavičius M. Influence of cyclic bending on prestress and shakedown of threaded joints. Mechanika, 1998, No I(12), Kaunas: Technologija, p. 11-19.

223. Leonavičius M., Stupak S. Influence of stress state on the crack imitation in the thread notch. Mechanika, 1998 , No I(12), Kaunas: Technologija, p. 5-10.

224. Leonavičius M. K. Cyclic fracture strength and shakedown of threaded joints and connected elements. Habilitation thesis. Vilnius: Technika, 1999. 96 p. (in Lithuanian).

225. Leonavičius M. Fliotovienè R. Stupak E. The stress-strain analysis in plates with operational and industrial defects. Archives of civil engineering, $X L V, 3,1999$, p. 443-452.

226. Leonavicius M., Stupak S. The stressed state and crack propagation in threaded joints. Proceedings of the NSCM - 11: Nordic Seminar on Computational Mechanics, Stocholm: Kungl Tekniska Hogskolan, 1998, p. 127-130.

227. Leonavičius M., Stupak S. Analysis of cyclic fracture of the threaded joints. Statyba (Civil Engineering), Vol VI, No 2, Vilnius: Technika, 2000, p. 97-103 (in Lithuanian).

228. Bazaras Z̆, Leonavičius M. Evaluation of the threaded joints progressing accumulation. Mechanika, 2000, No 2, Kaunas: Technologija, p. 13-17.

229. Marrow T. J., Centinel H., Venslovas A., Al Zalmah M. Leonavičius M. Short Fatigue Cracks in Ductile Cast Iron. Mechanika, 2001, No 3(29), Kaunas. Technologija, p. 510.

230. Maciulevičius D. Linear programming algorithms for synthesis of minimum weight statically determinate framed structures. Structural mechanics and structures, Vilnius: Mintis, 1966, p. 33-49 (in Russian).

231. Maciulevičius D., Čiučelis A. A random search algorithm for the optimal design of an elastic pin-jointed structure. Lith. Proc. in Mech., 1970, No 1(6), Vilnius, p. 136-143 (in Russian).

232. Baradokas P., Maciulevičius D. Synthesis of multilayer plate with maximum dissipation of vibratory energy. Lith. Proc. in Mech, 1971, No 2(9), Vilnius, p. 33-45 (in Russian).

233. Belevičius R. Shape optimization of laminated orthotropic plate structures. Mechanics of Composite Materials, Vol 29, No 4, 1993, p. 537-546.

234. Belevičius R. Computer algebra in finite element method. Vilnius: Technika, 1994. $184 \mathrm{p}$.

235. Belevičius R., Valentinavičius S. Optimization of grillagetype foundations. Statyba (Civil Engineering), Vol VI, No 4, Vilnius: Technika, 2000, p. 255-261.

236. Belevičius R., Valentinavičius S. Optimization problems for erection foundations. Lithuanian Mathematical Collection, Vol 40, Vilnius, 2000, p. 365-373 (in Lithuanian).

237. Michnevič E., Belevičius R. Element DKT_CST for analysis of laminated anisotropic plates. Statyba (Civil Engineering), Vol VI, No 5, Vilnius: Technika, 2000, p. 351356 (in Lithuanian).

238. Belevičius R., Valentinavičius S., Weener R. J. Optimization of grillage-type foundations. Proc. of 2 nd Worldwide ECCE Symposium "Information and Communication Technology in Practice of Building and Civil Engineering", Espoo, 2001, p. 251-256.

239. Baušys R. Higher order integration methods for structural dynamics problems. Statyba (Civil Engineering), 1996, No 3(7), Vilnius: Technika, p. 6-12.

240. Baušys R., Wiberg N. -E. Postprocessing techniques in finite element analysis. Mechanika, 2000, No 2(22), Kaunas: Technologija, p. 58-64.

241. Bausys R. Quality assesed finite element analysis for structural dynamic and acoustic problems. Habilitation thesis. Vilnius: Technika, 2000. 44 p. (in Lithuanian).

242. Baušys R. A new predictor-multicorrector algorithm for time integration in structural dynamics. Statyba (Civil Engineering), Vol VI, No 5, Vilnius, 2000, p. 345-350.

243. Čižas A. Conference on mathematical programming methods for optimal structural design (Vilnius, 9-12 July, 1969; review). Stroitelnaja mekhanika i raschet sooruzhenij, 1969, No 6, Moscow, p. 75-76 (in Russian). 


\section{APPENDICES}

Appendix 1. First scientific publications of A. Čyras

\begin{tabular}{|c|l|}
\hline No & \multicolumn{1}{|c|}{ Publication } \\
\hline 1. & $\begin{array}{l}\text { On investigations of bar structures by means of optical method: Abstract of Doctoral thesis. } \\
\text { Minsk: Polytechnical Institute of Belarus, 1954. 20 p. (in Russian). }\end{array}$ \\
\hline 2. & $\begin{array}{l}\text { Electronical fotometer for optical evaluation of stresses. Proceedings of Kaunas Polytechnical } \\
\text { Institute, Vol 3, 1955, p. 93-99. Co-authors: Nešukaitis V., Grinbergas E. (in Lithuanian). }\end{array}$ \\
\hline 3. & $\begin{array}{l}\text { Application of fotometer for stress evaluation. Equipment and stands, No 7, Academy of } \\
\text { sciences of the USSR, 1955, p. 12-14. Co-author: Nešukaitis V. (in Russian). }\end{array}$ \\
\hline 4. & $\begin{array}{l}\text { Design of bar structures applying optical method. Polarization-optical method for stress } \\
\text { evaluation. Moscow, 1956, p. 84-95 (in Russian). }\end{array}$ \\
\hline 5. & $\begin{array}{l}\text { Multistorey frame design by means of finite difference method. Proceedings of Kaunas } \\
\text { Polytechnical Institute, Vol 6, 1957, p. 3-7 (in Lithuanian). }\end{array}$ \\
\hline 6. & $\begin{array}{l}\text { Some Flaman problem solution cases. Proceedings of Kaunas Polytechnical Institute, Vol 9, } \\
\text { 1958, p. 49-53 (in Lithuanian). }\end{array}$ \\
\hline
\end{tabular}

Appendix 2. Chronology of Vilnius scientists engaged into structural mechanics research (1956-1992)

\begin{tabular}{|c|l|c|c|}
\hline No & \multicolumn{1}{|c|}{ Scientist } & $\begin{array}{c}\text { First } \\
\text { publi- } \\
\text { cation }\end{array}$ & $\begin{array}{c}\text { Doctoral, } \\
\text { Habilitation } \\
\text { theses }\end{array}$ \\
\hline 1. & Aleksandras Čyras & 1956 & 1954,1965 \\
\hline 2. & Daumantas Maciulevičius & 1964 & 1956,1969 \\
\hline 3. & Henrikas Gylys & 1965 & 1968 \\
\hline 4. & Romualdas Baronas & 1965 & 1968 \\
\hline 5. & Vidmantas Zakarevičius & 1966 & 1967 \\
\hline 6. & Algirdas Čižas & 1966 & 1967,1974 \\
\hline 7. & Adomas Borkauskas & 1967 & 1969,1978 \\
\hline 8. & Adolfas Šeputis & 1968 & 1970 \\
\hline 9. & Antanas Krutinis & 1968 & 1971 \\
\hline 10. & Leonas Lindišas & 1968 & 1973 \\
\hline 11. & Juozas Nagevičius & 1968 & 1971 \\
\hline 12. & Petras Baublys & 1969 & 1971 \\
\hline 13. & Rimantas Vèbra & 1969 & \\
\hline 14. & Algirdas Čiučelis & 1970 & 1973 \\
\hline 15. & Romanas Karkauskas & 1970 & 1972 \\
\hline 16. & Juozas Atkočiūnas & 1970 & 1973,1996 \\
\hline 17. & Petras Baradokas & 1971 & 1971 \\
\hline 18. & Mindaugas Leonavičius & 1972 & 1977,2000 \\
\hline 19. & Stanislovas Kalanta & 1972 & 1974 \\
\hline 20. & Bronislavas Mažuolis & 1972 & 1974 \\
\hline 21. & Petras Valiukonis & 1972 & \\
\hline 22. & Petras Čyras & 1973 & 1974 \\
\hline 23. & Viktoras Dulman & 1973 & 1975 \\
\hline 24. & Vidutis Kamaitis & 1973 & 1975 \\
\hline & & & \\
\hline
\end{tabular}

\begin{tabular}{|c|c|c|c|}
\hline No & Scientist & $\begin{array}{c}\text { First } \\
\text { publi- } \\
\text { cation }\end{array}$ & $\begin{array}{c}\text { Doctoral, } \\
\text { Habilitation } \\
\text { theses }\end{array}$ \\
\hline 25. & Alfonsas Kuzmickas & 1974 & 1975 \\
\hline 26. & Kęstutis Vislavičius & 1974 & 1977 \\
\hline 27. & Rimantas Belevičius & 1977 & 1986,1994 \\
\hline 28. & Davidas Džankarašvilis & 1977 & 1978 \\
\hline 29. & Stanislav Stupak & 1977 & 1978 \\
\hline 30. & Saulius Kaminskas & 1979 & 1982 \\
\hline 31. & Rimantas Kačianauskas & 1979 & 1982,1996 \\
\hline 32. & Jolanta Sinkevičiūtė & 1979 & \\
\hline 33. & Valentinas Skaržauskas & 1979 & 1982 \\
\hline 34. & Marijonas Šukšta & 1979 & 1982 \\
\hline 35. & Liudvikas Rimkus & 1981 & 1984 \\
\hline 36. & Lionginas Čiupaila & 1982 & 1984 \\
\hline 37. & Arūnas Komka & 1982 & 1990 \\
\hline 38. & Alfonsas Daniūnas & 1984 & 1985 \\
\hline 39. & Algirdas Sokas & 1985 & 1986 \\
\hline 40. & Nerijus Žukas & 1986 & 1986 \\
\hline 41. & Jurgis Medzvieckas & 1986 & 1989 \\
\hline 42. & Romualdas Baušys & 1987 & 1989,2000 \\
\hline 43. & Arûnas Komka & 1988 & 1990 \\
\hline 44. & Rasa Kazakevičiūtè & 1989 & 1990 \\
\hline 45. & Arnoldas Norkus & 1989 & 1990 \\
\hline 46. & Remigijus Kutas & 1990 & 1992 \\
\hline 47. & Saulius Valentinavičius & 1991 & 1992 \\
\hline
\end{tabular}


Appendix 3. Doctoral theses in structural mechanics (1954-1992)

The upper index marks the Doctoral thesis' supervisor: ${ }^{1}-$ V. Klimavičius, ${ }^{2}-$ A. Čyras, ${ }^{3}-$ A. Čižas, ${ }^{4}-$ A. Kudzys, ${ }^{5}-$ A. Borkauskas.

\begin{tabular}{|c|c|c|c|}
\hline No & Author & Doctoral thesis & Date \\
\hline 1. & A. Čyras & Research of building bar structures by optical method & 1954 \\
\hline 2. & J. Žukas' & Design of plates on deformable basement by optical-polarization method & 1962 \\
\hline 3. & A. Čižas ${ }^{2}$ & $\begin{array}{l}\text { Application of mathematical programming methods to analysis of elastoplastic beams and frames } \\
\text { with regards to deformation restrictions }\end{array}$ & 1967 \\
\hline 4. & V. Zakarevičius ${ }^{2}$ & Application of programming methods for calculations of elastic - plastic crossing beams structures & 1967 \\
\hline 5. & J. Barauskas & Research of stress-strain field in tapes and circular plates on soil base & 1968 \\
\hline 6. & H. Gylys ${ }^{2}$ & About experimental research of elastoplastic bar systems & 1968 \\
\hline 7. & R. Baronas ${ }^{2}$ & Linear programming methods to analysis of displacements of elastoplastic bar systems & 1968 \\
\hline 8. & A. Borkauskas ${ }^{2}$ & Dual principles of limit equilibrium theory and their application in plates design & 1969 \\
\hline 9. & A. Krutin is. ${ }^{1.3}$ & Design of elastoplastic structures on deformable ground for mathematical programming & 1971 \\
\hline 10. & P. Baublys' & Optimization problems of elastic buckling systems & 1971 \\
\hline 11. & J. Nagevičius ${ }^{2}$ & Design of elastic-plastic cylindrical shells by using linear programming & 1971 \\
\hline 12. & R. Karkauskas ${ }^{2}$ & The rigid-plastic spherical shell design under mathematic programming & 1972 \\
\hline 13. & J. Atkočiūnas ${ }^{2}$ & $\begin{array}{l}\text { Mathematical programming methods in optimization of elastic-plastic bodies under variable } \\
\text { repeated loading }\end{array}$ & 1973 \\
\hline 14. & A. Senuta ${ }^{1}$ & Design of circular plates on elastic basement & 1973 \\
\hline 15. & L. Lindišas ${ }^{2}$ & $\begin{array}{l}\text { Design of elastoplastic trusses taking into account element stability by means of mathematical } \\
\text { programming methods }\end{array}$ & 1973 \\
\hline 16. & V. Viršilas ${ }^{4}$ & $\begin{array}{l}\text { A cracking and strength conditions inclined cross-section investigation of prestressed variable height } \\
\text { reinforced concrete elements }\end{array}$ & 1973 \\
\hline 17. & S. Kalanta ${ }^{2}$ & Design problems of nonlinear rigid-plastic cylindrical shells & 1974 \\
\hline 18. & B. Mažuolis² & Analysis of the rigid plastic plates tasks by applying mathematical programming & 1974 \\
\hline 19. & P. Čyras ${ }^{5}$ & Some plain deformation problems of plastical rigid (locking) body & 1974 \\
\hline 20. & V. Kamaitis ${ }^{3}$ & Analysis and optimization of elastoplastic structures & 1975 \\
\hline 21. & V. Dulman ${ }^{2}$ & Application of mathematical programming methods in optimization problems of rigid creap systems & 1975 \\
\hline 22. & J. Žekevičius ${ }^{4}$ & I type cross-section variable height re in forced concrete bendable elements behavior investigation & 1975 \\
\hline 23. & K. Vislavičius ${ }^{2}$ & Optimization of discreet elastic-plastic structure ander moveable loading & 1977 \\
\hline 24. & M. Leonavičius ${ }^{2}$ & Investigation of the low cycle fracture in threaded joints & 1977 \\
\hline 25. & S. Stupak ${ }^{3}$ & $\begin{array}{l}\text { Analysis and optimization of real cross-sections bendable structures taking into account distribution } \\
\text { of plastic strains }\end{array}$ & 1978 \\
\hline 26. & D. Djankarashvili ${ }^{3}$ & $\begin{array}{l}\text { Investigation of prestressed cable structures with regard to material plasticity and geometric } \\
\text { nonlinearity }\end{array}$ & 1978 \\
\hline 27. & R. Kačianauskas ${ }^{2}$ & Yield Criterion of Finite Element and it's Application to Limit Analysis and Optimization of Shells & 1982 \\
\hline 28. & V. Skaržauskas ${ }^{2}$ & Analysis and optimization problems of the elastoplastic arches under various load & 1982 \\
\hline 29. & M. Šukšta ${ }^{3}$ & $\begin{array}{l}\text { The design and optimization of real cross-section bending structures made of straight hardening } \\
\text { material in the case of alternate variable load }\end{array}$ & 1982 \\
\hline 30. & A. Krenevičius ${ }^{3}$ & Low cycle fatigue of the threaded joints under high temperatures & 1983 \\
\hline 31. & L. Rimkus ${ }^{2}$ & $\begin{array}{l}\text { Evaluation of stress and strain field of elastic-plastic bar structures effected by repeated variable } \\
\text { temperature }\end{array}$ & 1984 \\
\hline 32. & L. Čiupaila ${ }^{2}$ & Evaluation of stress and strain field of elastic-plastic bar structures & 1984 \\
\hline 33. & A. Sokas ${ }^{2}$ & $\begin{array}{l}\text { Determination of the stress-strain field of ideal elastic-plastic spherical shells under nonsymmetrical } \\
\text { loading untill complete plastic failure }\end{array}$ & 1985 \\
\hline 34. & A. Daniūnas ${ }^{2}$ & Analysis of elastoplastic plates stress-strain field till plastical failure & 1985 \\
\hline 35. & N. Žukas ${ }^{2}$ & Design of closed round cylindrical shelis till plastical destruction & 1986 \\
\hline 36. & R. Baušys ${ }^{2}$ & Optimization of elastic-plastic bar systems under displacement constraints & 1989 \\
\hline 37. & J. Medzvieckas ${ }^{3}$ & Influence of support pliability on serviceability and optimization of framed structures & 1989 \\
\hline 38. & A. Komka ${ }^{3}$ & Analysis and optimization of framed structures with tubular composite members & 1990 \\
\hline 39. & R. Kazakevičiūté ${ }^{2}$ & Linearly hardening solid plane problem mathematical models by means of finite elements & 1990 \\
\hline 40. & A. Norkus ${ }^{2}$ & Design of elastic-plastic bar structures under determinated and random load combinations & 1990 \\
\hline 41. & S. Valentinavičius ${ }^{2}$ & Calculation of double curved shells till plastical destruction & 1992 \\
\hline
\end{tabular}


Appendix 4. The beginnings of A. Čyras' publications on optimization (1963-1967)

\begin{tabular}{|c|c|c|}
\hline No & Publication & Date \\
\hline 1. & $\begin{array}{l}\text { Design of staticaly indeterminate elastoplastic beams by linear programming methods. Statyba ir } \\
\text { architektüra, Vol 3, No 2, Vilnius, 1963, p. 5-21 (in Lithuanian). }\end{array}$ & 1963 \\
\hline 2. & $\begin{array}{l}\text { Application of linear programming methods for design of staticaly indeterminate structures. Statyba ir } \\
\text { architektüra, Vol 3, No 4, Vilnius, 1963, p. 16-17 (in Lithuanian). }\end{array}$ & 1963 \\
\hline 3. & $\begin{array}{l}\text { Application of linear programming methods for design of staticaly indeterminate structures. Stroitelstvo } i \\
\text { arkhitektura, } 1963, \text { No 6, p. 13-15 (in Russian). }\end{array}$ & 1963 \\
\hline 4. & $\begin{array}{l}\text { Design of staticaly indeterminate elastoplastic beams by linear programming methods. Statyba ir } \\
\text { architektüra, Vol 3, No 2, Vilnius, 1963, p. 5-21 (in Lithuanian). }\end{array}$ & 1963 \\
\hline 5. & $\begin{array}{l}\text { Elastoplastic frame design by of linear programming methods. Statyba ir architektūra, Vol 4, Vilnius, 1964, } \\
\text { p. 137-144 (in Lithuanian). }\end{array}$ & 1964 \\
\hline 6. & $\begin{array}{l}\text { Design of minimal weight frame under variable-repeated loading. Stroitelnaja mekhanika i raschet } \\
\text { sooruzhenij, } 1965 \text {, No 6, p. 14-17 (in Russian). }\end{array}$ & \\
\hline 7. & $\begin{array}{l}\text { Some application methods of mathematical programming in structural mechanics problems. News of } \\
\text { Academy of Sciences USSR, Technical cybemetics, } 1965, \text { No } 11, \text { p. 111-13 (in Russian). }\end{array}$ & 1965 \\
\hline 8. & $\begin{array}{l}\text { Design of frame structures using data of optical method. Polarization-optical method of stresses research, } \\
\text { A cademy of sciences of the USSR, Moscow, 1965, p. 59-65 (in Russian). }\end{array}$ & 1965 \\
\hline 9. & $\begin{array}{l}\text { Stochastic problems of elastoplastic one-dimensional systems design and their solution methods. Materials } \\
\text { of conference about application of reliability theory methods in structural mechanics (Moscow, 5-7 Oct., 1965), } \\
\text { Moscow, 1965, p. 18. Co-author: Seputis A. (in Russian). }\end{array}$ & 1965 \\
\hline 10. & $\begin{array}{l}\text { Dual problems of direct and verificational elastoplastic bar design. Civil engineering and architecture of } \\
\text { Uzbekistan, 1966, No 12, p. 14-43 (in Russian). }\end{array}$ & 1966 \\
\hline 11. & $\begin{array}{l}\text { Application of linear programming methods in elasto-plastic beams and frames design and their realization } \\
\text { by PC. PC in structural mechanics: Proceedings of meeting (Leningrad, 10-14 Dec., 1966), Leningrad- } \\
\text { Moscow, 1967, p. 207-215 (in Russian). }\end{array}$ & 1967 \\
\hline 12. & $\begin{array}{l}\text { On the rational approach to the problems of elastoplastic design of one-dimensional systems. Lith. Proc. in } \\
\text { Mech., 1967, No I, Vilnius, p. 29-33. Co-author: Čižas A. (in Russian). }\end{array}$ & 1967 \\
\hline 13. & $\begin{array}{l}\text { The elastic-plastic analysis of plates by linear programming. Lith. Proc. in Mech., 1967, No 1, Vilnius: Mintis, } \\
\text { p. 34-60. Co-author: Borkauskas A. (in Russian). }\end{array}$ & 1967 \\
\hline 14. & $\begin{array}{l}\text { Dual problems in deformation analysis of elastic-plastic one-dimensional systems. Lith. Proc. in Mech., } \\
1967, \text { No 1, Vilnius, p. 61-75. Co-author: Baronas R. (in Russian). }\end{array}$ & 1967 \\
\hline 15. & $\begin{array}{l}\text { Dual problems in deformation analysis of elastic-plastic one-dimensional systems. Lith. Proc. in Mech., } \\
1968, \text { No } 1(2) \text {, Viln ius, p. 100-111. Co-author Baronas R. (in Russian). }\end{array}$ & 1968 \\
\hline 16. & $\begin{array}{l}\text { Kinematic formulation of the elastic-plastic design considering limited deformations. Lith. Proc. in Mech., } \\
\text { No 1, Vilnius, 1967, p. 76-87. Co-author: Čižas A. (in Russian). }\end{array}$ & 1967 \\
\hline 17. & $\begin{array}{l}\text { Analysis of an elastic-plastic structural design considering limited deformations. Lith. Proc. in Mech., 1967, } \\
\text { No 1, Vilnius, p. 102-114. Co-author: Čižas A. (in Russian). }\end{array}$ & 1967 \\
\hline 18. & $\begin{array}{l}\text { Formulation of optimal elastoplastic crossing beams systems under single load design problems. Statyba ir } \\
\text { architektüra, Vol 2, 1967, p. 109-120. Co-author: Zakarevičius V. (in Lithuanian). }\end{array}$ & 1967 \\
\hline 19. & $\begin{array}{l}\text { Dual formulation of elasto-plastic beams and frames design problems taking into account limit } \\
\text { deformations. Proceedings of } 4 \text { th conference of strength and plasticity (Moscow, } 1-4 \text { Feb., 1967), Moscow, } \\
\text { 1967, p. 140. Co-auhor: Čzižas A. (in Russian). }\end{array}$ & 1967 \\
\hline
\end{tabular}


Appendix 5. Some structural mechanics research reports under A. Čyras' supervision (in Russian) (1968-1987)

\begin{tabular}{|c|c|c|}
\hline No & Research report & Date \\
\hline 1. & $\begin{array}{l}\text { V. Zakarevičius, J. Barauskas, R. Karkauskas. Design of elastoplastic systems formed from crossing beams. } \\
\text { Vilnius, 1968. } 212 \text { p. }\end{array}$ & 1968 \\
\hline 2. & $\begin{array}{l}\text { A. Borkauskas, R. Karkauskas, J. Barauskas, J. Nagevičius a.o. Design of elastoplastic structures by } \\
\text { mathematical programming. Part. 1. General theory of limit equilibrium optimal structural design. Vilnius, } \\
\text { 1971. } 107 \text { p. }\end{array}$ & 1971 \\
\hline 3. & $\begin{array}{l}\text { R. Karkauskas. Design of rigid plastical shallow spherical shelis by mathematical programming. Vilnius, } \\
\text { 1971. } 237 \text { p. }\end{array}$ & 1971 \\
\hline 4. & $\begin{array}{l}\text { R. Karkauskas, R. Baronas, J. Nage vičius. Design of elastoplastic structures by mathematical programming. } \\
\text { Part. 2. Design of shallow spherical shells. Vilnius, } 1972.300 \mathrm{p} \text {. }\end{array}$ & 1972 \\
\hline 5. & $\begin{array}{l}\text { R. Karkauskas, S. Kalanta, J. Nagevičius a.o. Design of elastoplastic structures by mathematical } \\
\text { programming. Part. 3. Design of plane cylindrical shells. Vilnius, } 1973.203 \text { p. }\end{array}$ & 1973 \\
\hline 6. & $\begin{array}{l}\text { J. Atkočiūnas, S. Kalanta, R. Karkauskas a.o. Design of elastoplastic structures subjected to variable } \\
\text { repeated loading. Part. 1. General design theory of elastoplastic structures affected repeated loading. Design } \\
\text { of optimal frame structures and rectangular plates. Vilnius, } 1974.217 \mathrm{p} \text {. }\end{array}$ & 1974 \\
\hline 7. & $\begin{array}{l}\text { J. Atkočiūnas, S. Kalanta, R. Karkauskas a.o. Design of elastoplastic structures subjected to variable } \\
\text { repeated loading. Part. 2. Design of circular plates and shallow shells of revolution applying finite element } \\
\text { and finite differences methods. Vilnius, } 1975.217 \mathrm{p} \text {. }\end{array}$ & 1975 \\
\hline 8. & R. Karkauskas, B. Mažuolis, J. Nagevičius. Design of rigid-plastic shells. Vilnius, 1975. 134 p. & 1975 \\
\hline 9. & $\begin{array}{l}\text { R. Karkauskas, J.Atkočiūnas a.o. Design of optimal elastoplastic rectangular shallow double curvature shells } \\
\text { with various boundary conditions. Part. } 1 \text {. General statements of rectangular shallow double curvature shells } \\
\text { subjected to by simple and variable repeated loading. Vilnius, } 1976.161 \mathrm{p} \text {. }\end{array}$ & 1976 \\
\hline 10. & $\begin{array}{l}\text { R. Karkauskas, J. Atkočiunas a.o. Design of optimal elastoplastic rectangular shallow double curvature } \\
\text { shells with various boundary conditions. Part. } 2 \text {. Design of double curvature shells subjected to simple } \\
\text { loading. Vilnius, } 1977.169 \text { p. }\end{array}$ & 1977 \\
\hline 11. & $\begin{array}{l}\text { R. Karkauskas, S. Kalanta, V. Dulman a.o. Design of optimal elastoplastic rectangular shallow double } \\
\text { curvature shells with various boundary conditions. Part. 3. Design of elastoplastic double curvature shells } \\
\text { subjected to variable repeated loading. Vilnius, } 1978.107 \mathrm{p} \text {. }\end{array}$ & 1978 \\
\hline 12. & $\begin{array}{l}\text { S.Kalanta, R.Kačianauskas, A.Daniūnas, R.Karkauskas. Elastoplastic plates and shells design algorithms and } \\
\text { programs by means of finite element method. Vilnius, } 1980.250 \mathrm{p} \text {. }\end{array}$ & 1980 \\
\hline 13. & $\begin{array}{l}\text { R. Karkauskas, J.Atkočiūnas, S.Kalanta. Elaboration of elastoplastic structural design algorithms and } \\
\text { programs by means of finite element method. Vilnius, } 1982.208 \text { p. }\end{array}$ & 1982 \\
\hline 14. & $\begin{array}{l}\text { R. Karkauskas, J.Atkociūnas, S.Kalanta a.o. Elaboration of structural design, evaluating plastic deformations } \\
\text { and various types of loads, algorithms, PC programs and recommendations for extended applications in } \\
\text { civil engineering. Vilnius, } 1985.189 \mathrm{p} \text {. }\end{array}$ & 1985 \\
\hline 15. & $\begin{array}{l}\text { J. Atkočiūnas, R. Karkauskas a.o. Elaboration of design recommendations for elastoplastic plate, subjected } \\
\text { constant and variable repeated loading. Vilnius, } 1987.139 \mathrm{p} \text {. }\end{array}$ & 1987 \\
\hline
\end{tabular}

